\title{
Bed material transport estimate in large gravel-bed rivers using the virtual velocity approach
}

\author{
Q1 Luca Mao, ${ }^{1 *}$ Lorenzo Picco, ${ }^{2}$ Mario A. Lenzi ${ }^{2}$ and Nicola Surian ${ }^{3}$ \\ ${ }^{1}$ Department of Ecosystems and Environment, Pontificia Universidad Católica de Chile, Santiago, Chile \\ 2 Department of Land, Environment, Agriculture and Forestry, University of Padova, Padova, Italy \\ ${ }^{3}$ Department of Geosciences, University of Padova, Padova, Italy
}

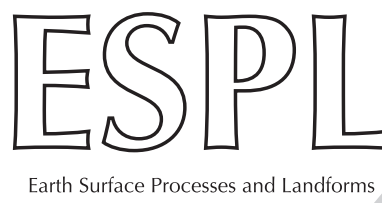

\begin{abstract}
This paper reports on a first attempt of using the virtual velocity approach to assess sediment mobility and transport in two wide and complex gravel-bed rivers of northern Italy. Displacement length and virtual velocity of spray-painted tracers were measured in the field. Also, the thickness of the sediment active layer during floods was measured using scour chains and postflood morphological changes as documented by repeated survey of channel cross-sections. The effects of eight and seven floods were studied on the Tagliamento and Brenta Rivers, where 259 and 277 spray-painted areas were surveyed, respectively. In the Tagliamento River $36 \%$ of the spray-painted areas experienced partial transport, whereas in the Brenta River this accounted for $20 \%$. Whereas, full removal/gravel deposition was observed on $37 \%$ and $26 \%$ of these areas on the Tagliamento and Brenta Rivers, respectively. The mean displacement length of particles, the thickness of the active layer and the extent of partial transport are well correlated with the dimensionless shear stress. The virtual velocity approach allowed calculation of bed material transport over a wide range of flood magnitudes. Annual coarse sediment transport was calculated up to 150 for the Tagliamento, and $30 \times 10^{3} \mathrm{~m}^{3} \mathrm{yr}^{-1}$ for the Brenta. The outcomes of this work highlight the relevance of partial transport condition, as it could represent more than $70 \%$ of the total bed material transported during low-magnitude floods, and up to $40 \%$ for near-bankfull events. Results confirm that bed material load tends to be overestimated by traditional formulas. Copyright @ 2016 John Wiley \& Sons, Ltd.
\end{abstract}

KEYWORDS: fluvial sediment transport; tracers; partial and full transport; scour chains; Italian Alps

\section{Introduction}

Bedload transport is one of the key drivers of river morphodynamics, thus proper and reliable estimations of this variable are needed by engineers, river ecologists, geomorphologists, and land-use planners. Bedload transport is commonly monitored using portable traps (e.g. Emmett, 1980; Bunte et al., 2004, 2007), but their use during flood events is potentially dangerous, and the results are biased by sources of errors and Q2 uncertainties (Vericat et al., 2006a; Bunte et al., 2008). To overcome these issues, indirect methods involving the use of vibration or sound generated by the impact of coarse particles on a plate or pipe (geophones, e.g. Rickenmann and McArdell, 2007; Rickenmann et al., 2012), or sound registered within the water column (hydrophones, e.g. Thorne and Hanes, 2002; Belleudy et al., 2010) have been recently tested and successfully applied (Rickenmann et al., 2014), even if they usually need to be calibrated with bedload data obtained via direct methods. Also, acoustic profilers have been effectively deployed (e.g. Rennie and Church, 2010), but need to be operated in the field during bedload-transporting events.

Advanced monitoring techniques are feasible in relatively small streams, but applications in wide gravel-bed rivers are rare. Experimental installations in the Drau River in Carinthia (Habersack et al., 2010; Rickenmann et al., 2014) and the
Elwha River in Washington (Hilldale et al., 2015), which are a few tens of metres wide are exceptions. In wide gravel-bed rivers, bed material rates can be estimated using the morphological method (Lane et al., 1995; Ashmore and Church, 1998; McLean and Church, 1999). The method has provided reasonably robust estimates of the time- and space-averaged bedload (Hicks and Gomez, 2003; Kasprak et al., 2015) but requires specification of bedload transport at a reference section, which is feasible only in some cases (e.g. downstream of a dam or at gravel-sand transitions). Also, the morphological method tends to perform better in long-term assessments or for high magnitude events that cause notable morphological changes.

A viable alternative for assessing bed material transport rates in wide gravel-bed rivers is provided by the virtual velocity approach. The method involves the estimation of the virtual velocity of particle movement $\left(V_{\mathrm{b}}\right.$, in $\left.\mathrm{m} \mathrm{h}^{-1}\right)$, the thickness of the active layer of the streambed $\left(d_{\mathrm{s}}\right.$, in metres), the active width of the streambed ( $W_{\mathrm{b}}$, in metres), and the porosity $(p)$ and density of the bed material $\left(\rho_{\mathrm{s}}\right.$, in $\left.\mathrm{kg} \mathrm{m}^{-3}\right)$, for calculating the mass rate of transport of bed material, $G_{\mathrm{b}}$ (in $\mathrm{kg} \mathrm{h}^{-1}$ ):

$$
G_{\mathrm{b}}=V_{\mathrm{b}} d_{\mathrm{s}} W_{\mathrm{s}}(1-p) \rho_{\mathrm{s}}
$$

The velocity of particle movement is called virtual because, by incorporating periods of both particle motion and rest, the 
virtual velocity is less than the actual velocity during particle movements. Haschenburger and Church (1998) used this method for assessing bed material load transport in Carnation Creek, a 10-15 m wide gravel-bed river in British Columbia. They measured the displacement length of magnetically tagged particles and the thickness of active sediment layers by using tracers and scour chains. These data enabled assessment of the relationships of virtual velocity, active depth, and active channel width with the flow strength, expressed in terms of stream power associated with the peak of monitored flood events. This finally led to a relation between transport rate and stream power (Haschenburger and Church, 1998). A similar approach was applied by Liebault and Laronne (2008) in a small gravel-bed river in France (Esconavette Torrent), and provided reasonable values of bed material load rates when compared with cumulative yield measured in a bedload trap.

The virtual velocity approach as applied by Haschenburger and Church (1998) and Liebault and Laronne (2008) cannot provide an estimation of fractional bed material load transport, and cannot distinguish between transport rates generated under partial and full mobility transport conditions. This issue can be overcome by using the framework developed by Wilcock (1997), who developed a theoretical framework for applying the virtual velocity approach by allowing the calculations of fractional sediment transport components, and distinguishing between partial and full mobility transport conditions. Wilcock (1997) refers explicitly to the mass and size distribution of sediment entrained in a certain unit area of the channel bed. Partial transport is the condition in which only a portion of the surface grains of a certain size are mobilized over the duration of a given transport event, while the full mobility condition refers to the condition in which all surface grains of a certain size are entrained during the transport event. This is how Wilcock and McArdell (1997) first defined partial and full mobility transport condition at the scale of a certain portion of the bed. The unit mass fractional transport rate $\left(q_{i}\right.$, in $\left.\mathrm{kg} \mathrm{m}^{-1} \mathrm{~s}^{-1}\right)$ is a function of both the virtual velocity of the $i$-size sediments $\left(V_{i}\right.$, in $\left.\mathrm{m} \mathrm{s}^{-1}\right)$, and the mass of sediments of the $i$-size entrained from a certain surface area over a certain time $\left(M_{i}\right.$, in $\left.\mathrm{kg} \mathrm{m}^{-2}\right)$ :

$$
q_{i}=M_{i} V_{i}
$$

Depending only on the flow strength as opposed to the duration of the transporting event, the virtual velocity of sediments should range around a constant mean for steady-state transport conditions (Wilcock, 1997). The mass of sediments entrained from the bed surface should also be independent of the duration of the transporting event for steady-state transport, and its value depends on the sediment transport conditions. If sediment entrainment occurs only from the bed surface (i.e. partial transport conditions), $M_{i}$ is given by:

$$
M_{i}=\frac{m_{i} F_{i} Y_{i}}{D_{i}^{2}}
$$

where $m_{i}$ is the mass of an individual grain of fraction $i$ (in kilograms), $F_{i}$ is the proportion of fraction $i$ in the surface grain size distribution, $D_{i}$ is the diameter of fraction $i$ (in metres), and $Y_{i}$ is the percentage of surface grains of the fraction $i$ that are entrained during the transport event. Wilcock (1997) calculated the mass of a grain of fraction $i$ using the spherical approximation as $m_{i}=\left((\pi / 6) \rho_{\mathrm{s}} \quad D_{i}\right)$. As stated by Wilcock (1997), Equation 3 would underestimate fractional entrainment at flows larger than those causing full surface mobilization of a certain fraction, because subsurface grains of that size could also be entrained. For this reason, at flow strengths higher than those that produce partial transport for a certain size, Equation 3 changes as follows:

$$
M_{i}=\frac{m_{i} F_{i}}{D_{i}^{3}} d_{s}
$$

where $Y_{i}$ disappears as it would be equal to one, and $d_{\mathrm{s}}$ is the exchange depth of sediments, or the thickness of the active sediment layer (in metres).

Wilcock's (1997) approach has the advantage of discriminating between partial and full transport conditions at the scale of unit area, thus separating conditions in which only the surface or subsurface sediments of each grain size are entrained. However, as suggested by Haschenburger and Wilcock (2003), partial transport could also be considered relative to the entire channel bed, indicating the active portion of all grains on the bed surface. Haschenburger and Wilcock (2003) demonstrated that the percentage of channel bed experiencing partial and full transport conditions depends on flow strength. At increasing discharges, areas of the bed under partial transport conditions increase as inactive areas decrease, and then areas under full transport conditions increase as areas under partial transport conditions decrease. Haschenburger and Wilcock (2003) showed that in the Carnation Creek approximately $25-50 \%$ of the bed experienced partial transport during a two-year recurrence interval flood, whereas nearly the whole cross-sections experienced full transport conditions during a seven-year recurrence interval flood. These observations highlight the importance of considering partial transport conditions during moderate but frequent flood events.

The objective of this work was to estimate bed material load transport in two wide and complex gravel-bed rivers of the eastern Italian Alps using the virtual velocity approach. We measured the displacement length and virtual velocity of particles entrained from spray painted areas, and the thickness of the active layer using scour chains and morphological changes on the study cross-sections. We used an approach similar to Haschenburger and Wilcock (2003) to examine the extent of partial transport and full mobility conditions in all morphological units within the active width of the two gravelbed rivers. We then applied the Wilcock (1997) approach for assessing sediment transport rates, distinguishing the relative contribution of partial and full mobility transport conditions for a relatively wide range of discharges. The virtual velocity approach of Wilcock (1997) has never been tested in wide gravel-bed rivers, and it could represent a viable alternative to direct sampling during floods. This approach also has the capability of capturing the high spatial and temporal variability that characterizes sediment transport in wide gravel-bed rivers.

\section{Materials and Methods}

\section{Study sites and analysed flood events}

The study was carried out in two gravel-bed rivers draining from the eastern Italian Alps to the Adriatic Sea, the Tagliamento and Brenta Rivers (Figure 1). The Tagliamento F1 River is located in the south-eastern Italian Alps. Its drainage basin covers $2871 \mathrm{~km}^{2}$, and in its piedmont reach the river features a braided pattern with very active island formation/ erosion dynamics and ecological values (e.g. Tockner et al., 2003; Bertoldi et al., 2010). The reach selected for this study is located near the village of Cornino (Figure 2), and corresponds F2 approximately with the Cornino reach as identified by Bertoldi et al. (2010). It is a very dynamic braided system with sparse 

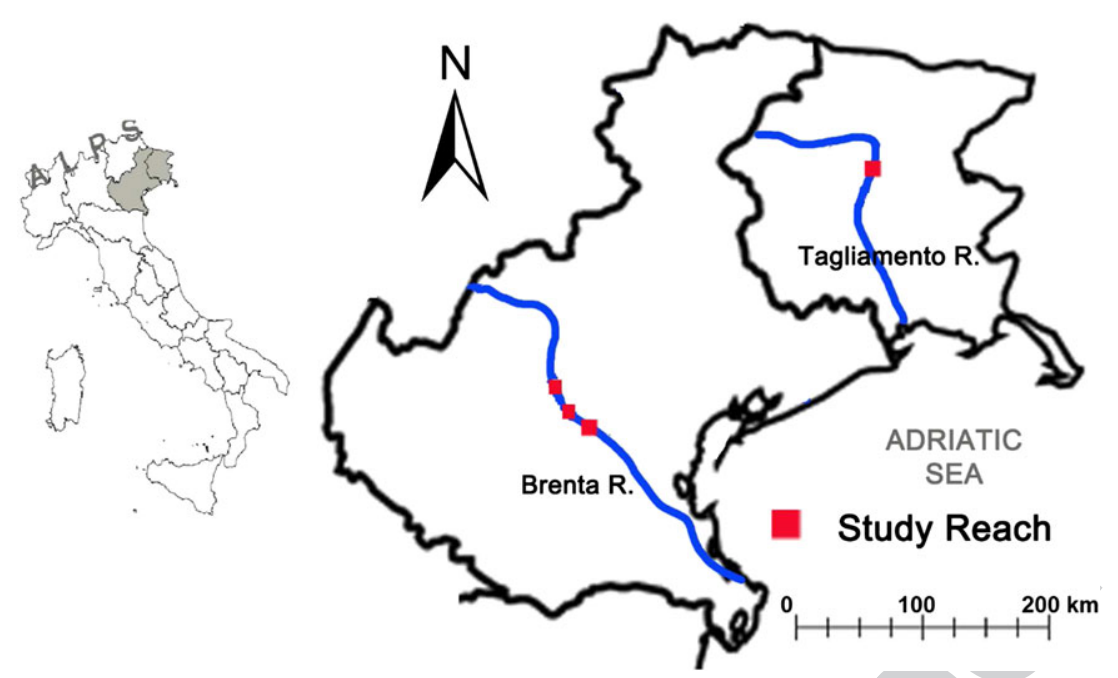

Figure 1. Location of the study sites.
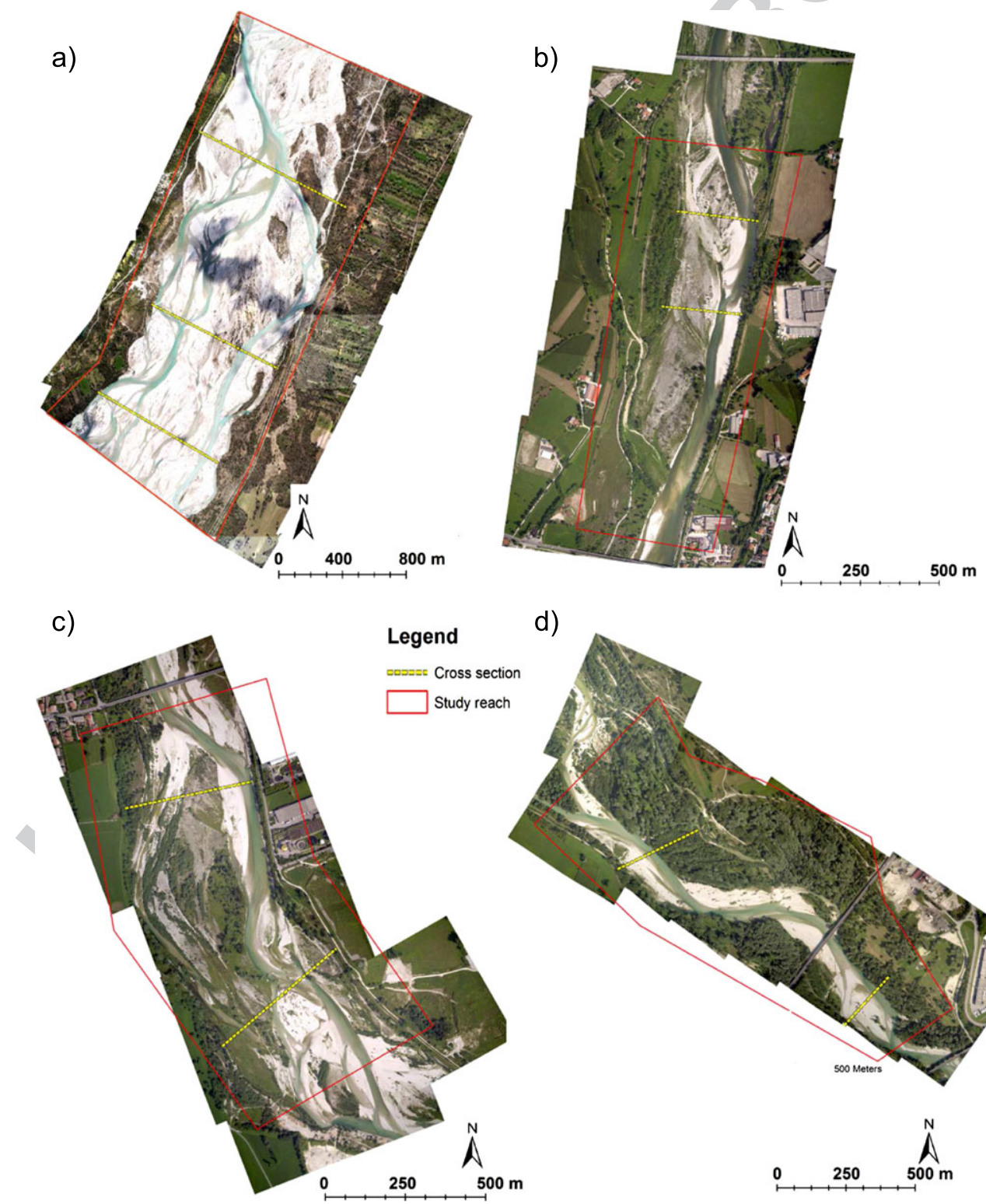

d)

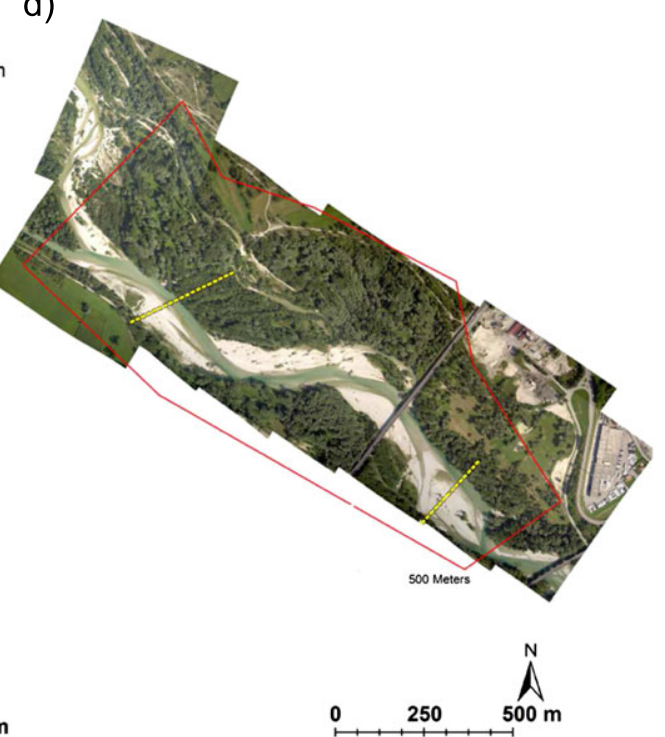

Figure 2. The study reaches on the Tagliamento (Cornino, a) and Brenta Rivers (Nove, b; Friola, c; Fontaniva, d) delimited by red lines. The analysed cross-sections are identified in yellow.

patches of shrubby vegetation: bankfull width is up to $1 \mathrm{~km}$ wide; slope is $0.0034 \mathrm{~m} \mathrm{~m}^{-1}$; and the median grain size $\left(D_{50}\right)$ is approximately $25 \mathrm{~mm}$.
The Brenta River drains an area of $1567 \mathrm{~km}^{2}$. In its middle course in the piedmont area, the Brenta River features patterns ranging from braided to wandering (Surian and Cisotto, 2007; 
Moretto et al., 2014). Three reaches of the Brenta River were considered in this study: Nove, Friola, and Fontaniva, named after the villages nearby (Figure 2). The Nove reach is immediately downstream of the mountain area, and features a fairly coarse and straight channel and narrow alluvial plain (slope $=0.0039 \mathrm{~m} \mathrm{~m}^{-1} ; D_{50}=37 \mathrm{~mm}$; bankfull width $=390 \mathrm{~m}$ ). The Friola reach is approximately $5 \mathrm{~km}$ downstream, where the river has an island braided pattern, and is influenced by bridges and rip-rap (slope $=0.0026 \mathrm{~m} \mathrm{~m}^{-1} ; D_{50}=35 \mathrm{~mm}$; bankfull width $=272 \mathrm{~m}$ ). In its far lower reach, called Fontaniva, the river exhibits a wandering pattern with higher sinuosity and extensive riparian vegetation on floodplain (slope $=0.0031 \mathrm{~m} \mathrm{~m}^{-1} ; D_{50}=31 \mathrm{~mm}$; bankfull width $=316 \mathrm{~m}$ ).

During the study period (June 2010-July 2011), the Tagliamento and Brenta Rivers experienced several flood events of different magnitude including near-bankfull events

F3 in November-December 2010 on both rivers (Figure 3). Discharge data recorded at the Barzizza gauging station, located $5 \mathrm{~km}$ upstream of the Nove reach, are available for the Brenta River. The station registered 11 events with discharge higher than $100 \mathrm{~m}^{3} \mathrm{~s}^{-1}$ during the study period. For the Tagliamento River, only flow stage measurements are available from the nearest gauging station (Villuzza), located $8 \mathrm{~km}$ downstream of the study reach. During the study period, 13 flood events with water stage higher than $1 \mathrm{~m}$ were registered. Post-flood surveys (conducted as soon as possible after the events) are available for eight and seven events in the T1 Tagliamento and Brenta Rivers, respectively (Table I).

\section{Estimate of sediment transport by virtual velocity approach}

Grain size measurement and painting of selected sites Three cross-sections were identified on the Tagliamento River (Cornino reach), and two cross-sections were established on each reach of the Brenta River (Figure 2). Cross-sections were surveyed in June 2010 using a differential global positioning system (dGPS), with a maximum vertical error of $0.03 \mathrm{~m}$. All changes of slope along the sections were measured, with an average point density of one point per $3 \mathrm{~m}$ of channel width. Along the cross-sections, a number of sites were selected as being representative of all morphological units apart from the main wet channel and islands (i.e. low bars, high bars, and secondary channels), and for being homogeneous (i.e. lack of large wood accumulation, local scour, lack of sand deposition over gravel, and dense herbaceous vegetation nearby). Low bars were considered areas with coarse bed material, low fine material, and absence of densely established herbaceous vegetation; high bars were considered areas with significant proportion of fine material in the surface, well-established herbaceous vegetation or sparse shrub cover; and secondary channels were identified as low areas of the cross-sections coincident with an obvious preferential flow path. No sites were selected on the floodplains or islands. The selected sites ranged from 10 to 20 , and from 8 to 16 per each cross-section in the Tagliamento and the Brenta Rivers, respectively. At those sites, the global positioning system (GPS) position and vertical digital photographs of the bed surface were taken. A wooden square with protruding metal wires was used to precisely define an area of $0.8 \mathrm{~m} \times 0.8 \mathrm{~m}$ (Figure 4). The photographs, F4 collected using a 16 Mpixels camera, were processed with the Digital Gravelometer software (Graham et al., 2005, 2010) in order to derive the surface grain size distribution of each site, with a lower truncation of $4 \mathrm{~mm}$. In the same Tagliamento River, previous applications of the photographic method assessed errors to be around $10 \%$ for the $D_{50}$, due to inclination of individual grains relative to the plane of the image, partial hiding of grains, and image-processing errors (Mao and Surian, 2010). After the photographs were taken, the surface of the photographed area was painted using a fast-drying spray paint to avoid percolation. Wooden wings hinged inside the square frame masked the surrounding bed surface and facilitated painting of the exact area that had been photographed (Figure 4).

Assessment of sediment mobility and measurement of sediment travel distance

All the painted areas were visited after all major flood events (i.e. with evidence of sediment transport on some portions of the channel; i.e. nine in the Tagliamento River and eight in the Brenta River, see Table I) during the study period (June 2010 July 2011). At each visit, the painted sites were photographed again, and all the painted particles moved by the floods and visible downstream of the coloured areas were collected. Their size and the distance travelled from the centre of the painted site were measured using a calliper and a tape, respectively. Similarly to Mao and Surian (2010), a range of effects of the flow on the painted areas was recognized. The coloured area could have remained unaffected by the flow or could have suffered only deposition of sand above the coloured gravel (Figure 5a). F5 A further effect of partial transport [intended here sensu Haschenburger and Wilcock (2003)] was identified when some surface-painted particles (irrespective of their diameter) moved whereas other particles remained immobile in the painted area and did not experience noticeable erosion/deposition during the flood event (Figure 5b). If no coloured particles were found where the area was spray painted in the previous visit, field evidence of incision (i.e. full removal of the coloured particles, Figure 5c) or deposition (i.e. sedimentation over the coloured
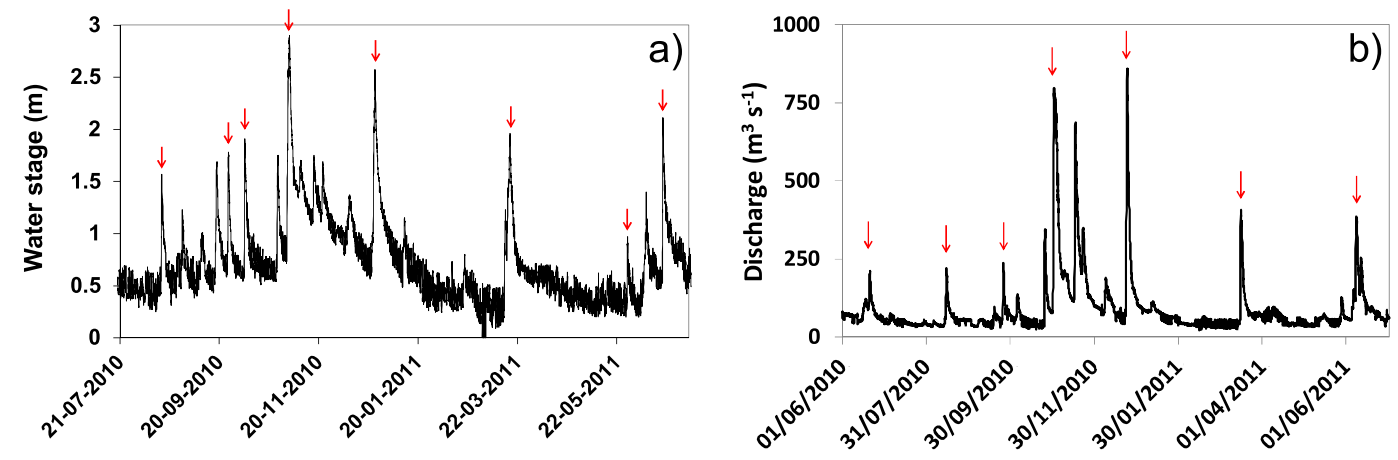

Figure 3. Characteristics of the flood events monitored in the Tagliamento (a) and Brenta Rivers (b) during the study period (June 2010-July 2011). The vertical arrows identify the events for which post-flood surveys are available. 
Table I. Characteristics of the flood events monitored in the Tagliamento and Brenta Rivers during the study period.

\begin{tabular}{|c|c|c|c|c|c|c|c|c|c|}
\hline Tagliamento & $H_{\max }(\mathrm{m})$ & $\begin{array}{r}\text { Duration } \\
\text { (hours) }\end{array}$ & $\begin{array}{c}\text { ER } \\
\left(\mathrm{m} \times 10^{-3}\right)\end{array}$ & RI (years) & Brenta & $\begin{array}{l}Q_{\max } \\
\left(\mathrm{m}^{3} \mathrm{~s}^{-1}\right)\end{array}$ & $\begin{array}{r}\text { Duration } \\
\text { (hours) }\end{array}$ & $\begin{array}{c}\text { ER } \\
\left(\mathrm{m}^{3} \times 10^{-3}\right)\end{array}$ & RI (years) \\
\hline 15 August 2010 & 1.57 & 114 & 179 & $<1$ & 21 June 2010 & 210 & 162 & 13374 & $<1$ \\
\hline 25 September 2010 & 1.78 & 86 & 153 & $<1$ & 15 August 2010 & 220 & 223 & 39321 & $<1$ \\
\hline 5 October 2010 & 1.91 & 71 & 181 & $<1$ & 25 September 2010 & 237 & 340 & 53979 & 1 \\
\hline 1 November 2010 & 2.90 & 172 & 683 & 2.2 & 1 November 2010 & 796 & 895 & 375844 & 8 \\
\hline 24 December 2010 & 2.57 & 227 & 430 & 1.7 & 24 December 2010 & 859 & 370 & 215019 & 10 \\
\hline 17 March 2011 & 1.96 & 243 & 765 & $<1$ & 16 March 2011 & 407 & 194 & 75302 & 2 \\
\hline 28 May 2011 & 0.97 & 75 & 79 & $<1$ & 8 June 2011 & 385 & 296 & 115560 & 1.5 \\
\hline 19 June 2011 & 2.11 & 194 & 410 & $<1$ & & & & & \\
\hline
\end{tabular}

Note: $H_{\max }$ is the water stage at the peak of the flood, $Q_{\max }$ is the water discharge at the peak of the flood, ER is the effective runoff for each single event calculated as the hydrograph volume above the base-flow of the previous day, and RI is the recurrence interval of the peak flow. Because only flow stage measurements are available for the Tagliamento River, the effective runoff represents the integrated area of the hydrograph, and not the actual discharge volume.
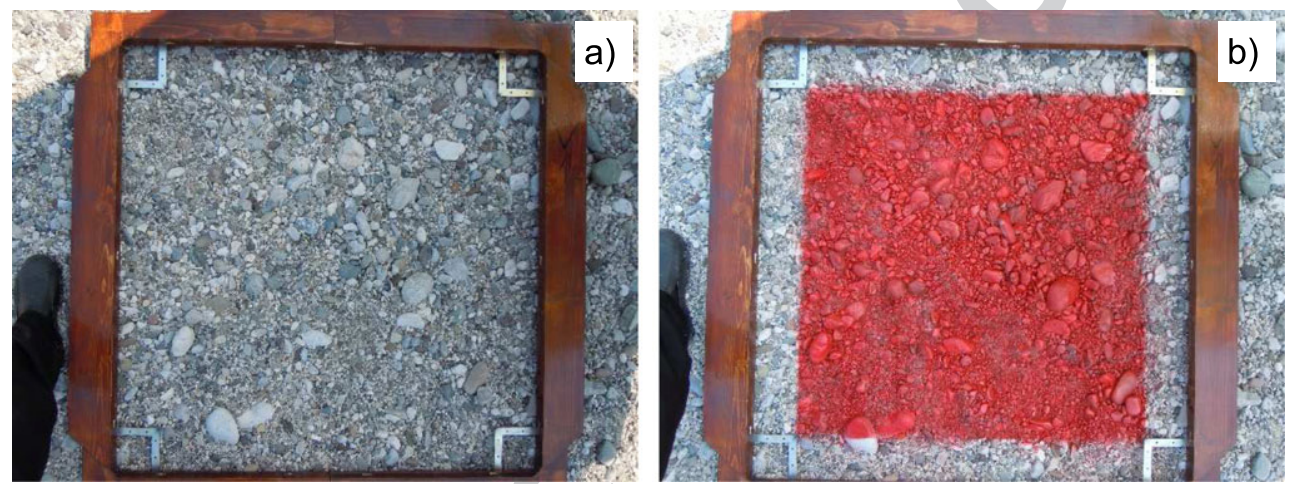

Figure 4. Images of the wooden frame used to identify an area of $0.8 \mathrm{~m} \times 0.8 \mathrm{~m}$, and to allow the painting of the same area with coloured spray paint.
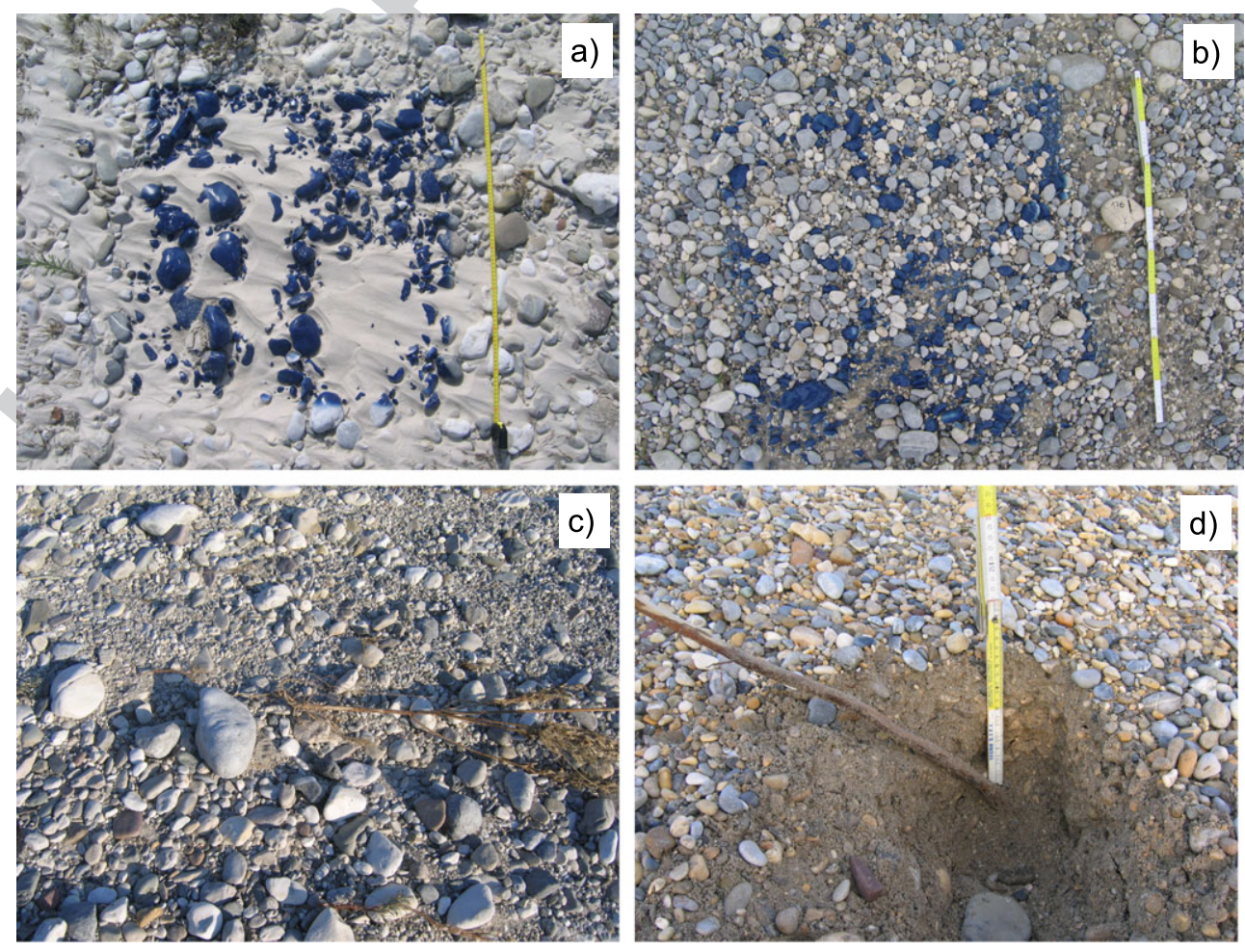

Figure 5. Classification of the effects of floods over the painted areas showing an example of fine deposition over the gravel framework (a), partial transport of coloured gravel (b), full removal of the coloured area (c; the exposed roots of a plant provided evidence of incision around the GPS point where the sample position was located), and gravel deposition over the coloured area (d; the layer of sediments partially covering the bended steam of a plant provided evidence of deposition around the GPS point where the sample position was located). 
particles Figure 5d) was observed, and was named full removal/gravel deposition as in Mao and Surian (2010). Precise values of erosion/deposition thickness over the coloured areas were calculated by comparing pre- and post-cross-sections, which were resurveyed at each field visit. The patches were repainted after each visit with a different colour in order to distinguish sediments moved by earlier floods.

Estimate of sediment active layer

The thickness of erosion/deposition was assessed in the field using scour chains. They record the event-based maximum depth of scour and the net deposition (Laronne et al., 1994; Liebault and Laronne, 2008). Scour chains were installed along the cross-sections, in proximity to coloured areas. The number of scour chains ranged from three to six, and from three to five per each cross-section in the Tagliamento and the Brenta Rivers, respectively. We searched for scour chains with a metal detector (detection range of about $0.2 \mathrm{~m}$ ) at each visit. However, because this search was very time consuming, data are available for only the first three and two post-flood surveys in the Tagliamento and the Brenta Rivers, respectively, as the search was abandoned in the second half of the study period.

In order to quantify the depth of bed scour, or exchange depth of sediments $d_{\mathrm{s}}$, for the portions of the bed that experienced total transport (i.e. all surface grains are removed or fully covered by a layer of sediments), evidence provided by scour chains and post-flood cross-section resurveys was used. Scour chains worked well for assessing vertical erosion of surface sediments as they could be easily identified in the field around the GPS position as registered when installed in the field. In contrast, when the morphological units experienced aggradation greater than $0.2 \mathrm{~m}$, the recovery of the scour chains was challenging even using a portable metal detector. For this reason, a comparison of topographical surveys pre- and postevents proved to be a good way of integrating the data. We excluded seven unreasonably high values of bed scour (i.e. $>$ $1.5 \mathrm{~m})$, most often linked to bank erosion due to lateral migration of the main or secondary channels, which was a relatively frequent case especially in the Tagliamento River.

Overall, 17 and 28 scour chain measurements of erosion/ sedimentation (i.e. exchange depths of sediments) were collected in the Tagliamento and the Brenta Rivers, respectively, and 83 and 72 vertical erosion/deposition thickness were derived from cross-section comparisons in the Tagliamento and the Brenta Rivers, respectively. Since the aim was to assess the thickness of exchange depth of sediments, erosion and deposition cases were treated as absolute values, thus always positive.

Estimate of shear stress and duration of competent flows In order to estimate the shear stress acting on the flooded painted areas, at each visit the maximum flow depth over each painted area was estimated from field evidence, such as lines of organic debris and fine sediments either on higher morphological units or on the rigid stems of herbaceous and shrubby plants. Shear stress was calculated through the depth-slope approach (Wilcock, 1993) $\tau=\rho g h S$ where $\rho$ is the density of water, $g$ is the acceleration due to gravity, $h$ is the flow depth over the painted area at the peak of the hydrograph, and $S$ is the local bed slope derived from a longitudinal profile $600-\mathrm{m}$ long obtained from LiDAR (light detection and ranging) surveys available for the study reaches. The dimensionless shear stress $\left(\tau^{*}\right)$ was then calculated using the local median grain size $\left(D_{50}\right)$ derived for each coloured area from the photographic analysis using Equation 5, in which $\rho_{\mathrm{s}}$ is the density of sediments:

$$
\tau^{*}=\frac{\tau}{\left(\rho_{s}-\rho\right) g D_{50}}
$$

The virtual velocity of sediments is calculated by dividing their displacement length by the duration of the flow with dimensionless shear stress above thresholds identified in the field as significant for determining partial or full transport conditions. In order to assess the duration of the flow on each painted area, the hydrographs as measured at the gauging stations needed to be transposed to each cross-section. To do so, a regression between the flood peaks registered at the gauging stations and the maximum water stage reached on each cross-section was obtained (Figure 6). The regressions ob- F6 tained for each cross-sections were then used to calculate water stage over time on each cross-section for each flood event. The obtained regressions have $R^{2}$ of at least $0.91(P<0.001$; standard error (SE) of the estimate $=0.12 \mathrm{~m}$ ) and 0.88 $(P<0.001$; SE of the estimate $=0.19 \mathrm{~m})$ in the Tagliamento and Brenta Rivers, respectively.

Estimate of the extent of partial transport

To quantify the extent of partial transport, 41 vertical photographs of the painted areas are available for the Tagliamento
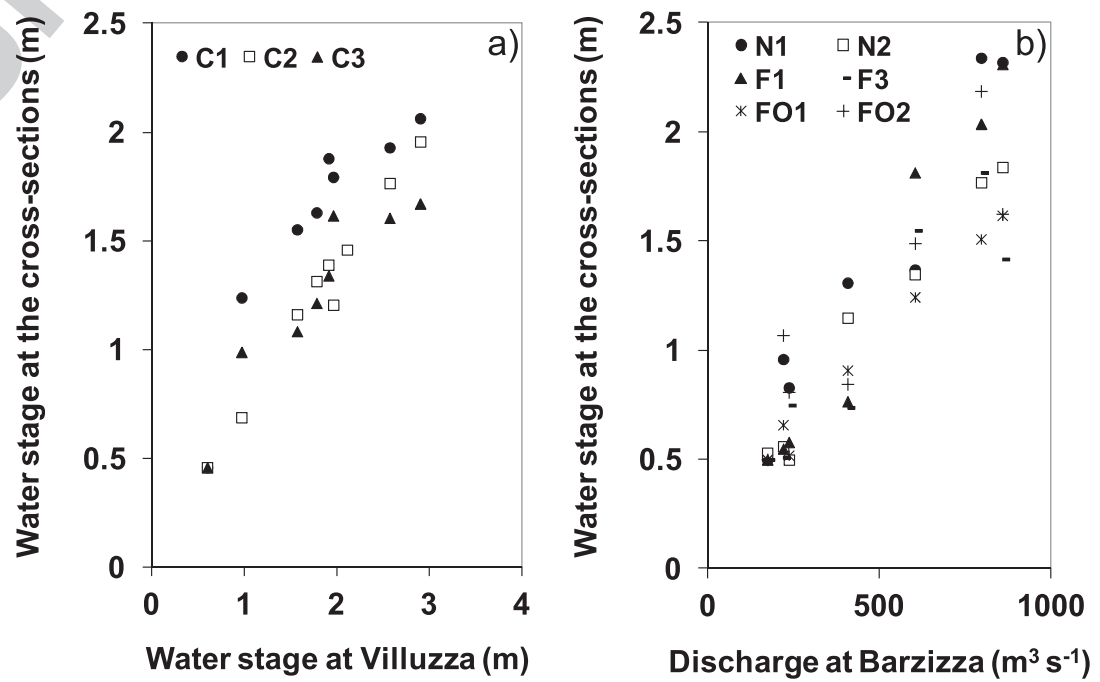

Figure 6. Relationships between peak floods measured at the gauging stations and maximum flow stage measured with post-flood surveys at each cross-section in the Tagliamento (a) and Brenta Rivers (b). 
River, whereas only a few photographs are available for the Q4 Brenta River. The red-green-blue (RGB) photographs were cut as much as possible to the original size of the coloured area, and analysed with Adobe Photoshop (Version CS4) in order to count the number of coloured pixels. The fraction of coloured pixels could range from zero to one, corresponding to conditions ranging from complete immobility to full removal

F7 of all particles (Figure 7). The percentage of coloured particles is thus considered a proxy for the extent of partial transport at the local scale (i.e. $Y=1$ - proportion of painted grains remaining in the coloured areas), which could be used to determine the factor $Y$ of Equation 3.

\section{Estimate of bed material transport using the virtual velocity approach}

Bed material transport $(D>4 \mathrm{~mm})$ was calculated for each cross-section under study (three in the Tagliamento River and six in the Brenta River), for each flood event that occurred and was surveyed over the study period (June 2010-July 2011). The water stage on the study cross-sections during the selected floods was calculated by using hourly data provided by the gauging stations (Barzizza and Villuzza, for the Brenta and Tagliamento Rivers, respectively), and the relationships between water stage at the cross-sections and the data provided by the gauging stations as derived from the post-flood field surveys (Figure 6). This allowed the calculation of the water stage, the shear stress, and the dimensionless shear stress on each $1 \mathrm{~m}$-wide portion of the cross-sections for each one-hour time step of the explored floods. The dimensionless shear stress was calculated using Equation 5. As for the grain size used to calculate the dimensionless shear stress for each $1 \mathrm{~m}$-wide portion of the cross-sections, because no significant relationship could be found between $D_{50}$ and morphological units or relative heights of the morphological units on the cross-sections, we used the same $D_{50}$ for each cross-section. The values of $D_{50}$ used in the calculations were 21.1, 23.9, and $22.1 \mathrm{~mm}$ for Cornino 1, 2, and 3 of the Tagliamento River, and 37, 35, and $31 \mathrm{~mm}$ for Nove, Friola, and Fontaniva reaches of the Brenta River. These were calculated as the averaged value of all $D_{50}$ derived from all the vertical photographs, taken before colouring the spray-painted areas, along the same crosssections.

The unit fractional sediment transport rate $\left(q_{i}\right.$, in $\mathrm{kg} \mathrm{m}^{-1} \mathrm{~s}^{-1}$, for $D_{i}>4 \mathrm{~mm}$ ) was calculated using Equation 2 on each $1 \mathrm{~m}$ wide portion of the cross-sections for each hourly value of discharge. The virtual velocity of grains of each $i$-fraction coarser than $4 \mathrm{~mm}$ was calculated as a function of the dimensionless shear stress acting on the bed, using empirical equations as $V=f\left(\tau^{*}\right)$ in the case of full transport (i.e. Equations 8 and 9 in the Results section, for the Tagliamento and Brenta Rivers, respectively) and empirical equations as $V=f\left(\tau^{*} ; D_{i}\right)$ in the case of partial transport (i.e. Equations 12 and 13 in the Results section, for the Tagliamento and Brenta Rivers, respectively). The mass of sediments of the $i$-size entrained and transported from each $1 \mathrm{~m}$-wide portion of the cross-sections $\left(M_{i}\right)$ was calculated using Equations 3 or 3, depending upon whether partial or full transport conditions were identified, respectively. For applying Equation 3, $Y_{i}$ was calculated using the empirical dependence of $Y$ on $\tau^{*}$ as identified in the field (i.e. Equation 14 in the Results section). For conditions in which $\tau^{*}$ is considered to produce full transport conditions, Equation 4, was applied, considering the empirical dependence of the thickness of active sediment layer on $\tau^{*}$ using empirical equations as $d_{s}=f\left(\tau^{*}\right)$ derived for both the Tagliamento and Brenta Rivers (i.e. Equations 6 and 7 in the Results section, for the Tagliamento and Brenta Rivers, respectively).

In order to compare the results obtained using the virtual velocity approach with commonly used bed material transport formulas, Meyer-Peter and Müller (1948), as modified by Wong and Parker (2006), and Wilcock and Crowe (2003) formulas were applied as well (for $D_{i}>4 \mathrm{~mm}$ ), using $\tau_{c}^{*}$ equal to 0.056 which is commonly quoted as the Shields number even if it could be strongly affected by local conditions of slope, roughness, and elative submergence among other factors (e.g. Buffington and Montgomery, 1997; Lamb et al., 2008).

\section{Results}

\section{Shear stress and morphological effects on painted areas}

Of the 259 coloured areas in the Tagliamento River, $10 \%$ of them were too high to be reached by the flow, and $16 \%$ of the areas experienced no effects or only deposition of fine sediments over the gravel bed. In $36 \%$ and $38 \%$ of the coloured areas the effects were recognized as partial transport and full removal/gravel deposition, respectively. Due to the different geometry of cross-sections and range of floods that occurred during the study period, these percentages are different for each cross-section, but all classes of bed response are well represented. In the Brenta River, of the 277 coloured areas surveyed on six cross-sections, $20 \%$ and $26 \%$ of them experienced partial transport and full removal/gravel deposition, respectively.

As expected, the higher the dimensionless shear stress acting on the bed (i.e. the shear stress experienced by a coloured area at the peak of a flood event), the greater the effects experienced by the painted areas in terms of gravel entrainment (Figure 8). F8
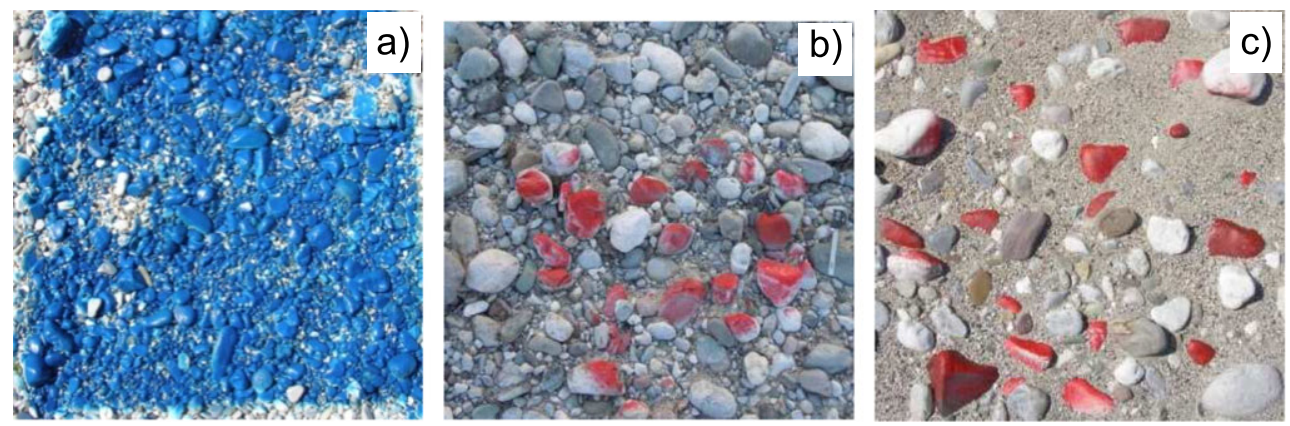

Figure 7. Range of conditions of the coloured areas after flood, which could range from near immobility to quasi-full mobility (the estimated fraction of mobilized area $Y$ corresponds to $0.1,0.5$, and 0.8 for the pictures $a, b$, and c, respectively). 


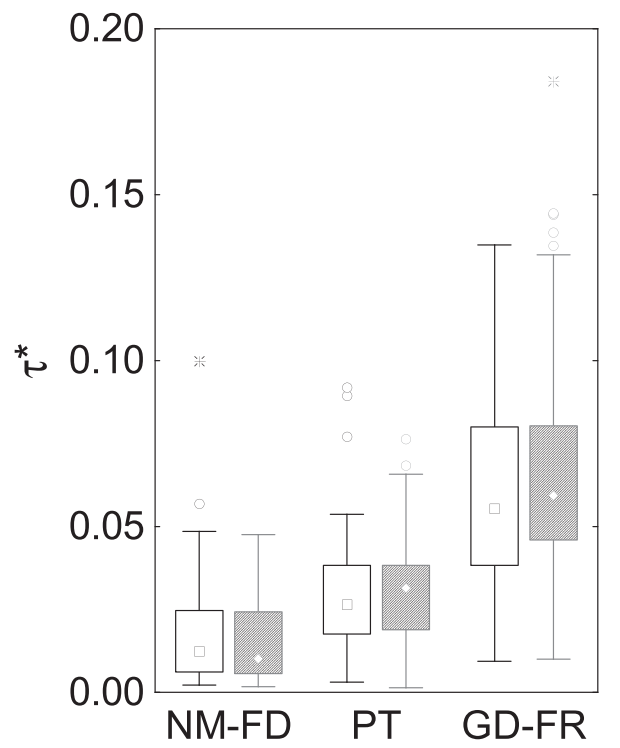

Figure 8. Range of dimensionless shear stress acting over the painted particles that induced certain effects in terms of sediment entrainment (NM, no sediment motion nor deposition; FD, deposition of fine sediments; PT, partial transport; GD, gravel deposition; FR, full removal of the painted sediments). White and dashed boxes represent the Brenta and the Tagliamento Rivers, respectively. The square within each box indicates the median value, box ends are the 25 th and 75 th percentiles, whiskers ends are the 10th and 90th percentiles, and lose points are outliers and extreme values.

Data cluster well among three classes of gravel entrainment: no motion, partial transport, and full transport (all coloured sediments are removed, and the morphological unit experienced visible deposition or erosion). The three classes are statistically different for both rivers [Kruskal-Wallis one-way analysis of variance (ANOVA) $H(N=232)=112.27, P<0.001$ for the Tagliamento River; and $H(N=221)=72.93 ; P<0.001$ for the Brenta River]. Full transport is likely to occur at values of $\tau^{*}$ higher than 0.04, whereas partial transport seems likely to occur at values of $\tau^{*}$ between 0.02 and 0.04 .

Shear stress and the thickness of the active layer of sediments

F9 Figure 9 shows that the active layer thickness increases as dimensionless shear stress increases. The regressions obtained for the rivers under study (Equations 6 and 7 for the Tagliamento and Brenta Rivers, respectively) are the following:

$$
\begin{array}{ll}
d_{s}=2.897 \tau^{* 0.919} & \left(R^{2}=0.507 ; P<0.01\right) \\
d_{s}=3.578 \tau^{* 0.891} \quad\left(R^{2}=0.477 ; P>0.05\right)
\end{array}
$$

The SE of the estimates is $0.24 \mathrm{~m}$ and $0.17 \mathrm{~m}$ for Equations 6 and 7 , respectively. Data show a considerable scatter, as for a certain dimensionless shear stress, the observed thickness of the active layer can span at least one order of magnitude. Scour chains measured active layer thickness up to $0.15 \mathrm{~m}$, whereas the comparison of cross-sections quantified vertical aggradation-incision up to $1 \mathrm{~m}$ for dimensionless shear stresses approaching 0.1 . The ranges of values provided by crosssection comparisons and scour chains are comparable. Also, using the one-way analysis of covariance (ANCOVA) test, data

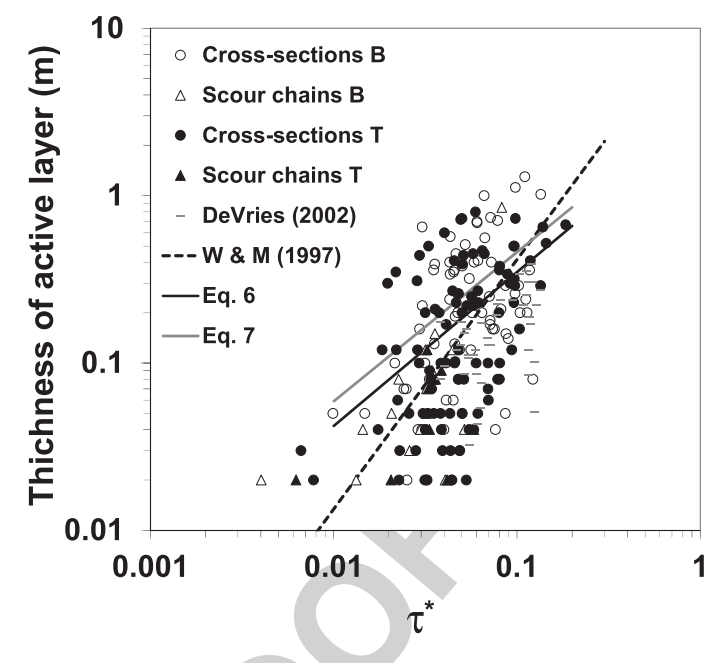

Figure 9. Thickness of active layers versus dimensionless shear stress measured in the Tagliamento and Brenta Rivers. Equations 6 and 7 are plotted along with field data from DeVries (2002), and Wilcock and McArdell (1997) empirical formula.

from the Tagliamento and Brenta Rivers, were found to be significantly similar $(F=32.61 ; P>0.01)$.

\section{Shear stress and virtual velocity of sediments}

All coloured sediments found within $10 \mathrm{~cm}$ from the downstream end of the spray painted area were not considered, as sometimes their movements appeared to be due to rainfall splashing. Also, all coloured areas with less than 10 grains transported for distances shorter than $10 \mathrm{~cm}$ from the downstream end of the coloured area were discarded from the following analysis, as it proved difficult to obtain reliable grain size curves of transported sediments. Overall, 31 and 32 coloured areas featuring partial transport conditions were fully surveyed in the Tagliamento and Brenta Rivers, respectively. Since displacement lengths were measured from the centre of the spray painted areas, the minimum surveyed values are approximately $50 \mathrm{~cm}$. Overall, 7465 and 6990 coloured grains were collected and measured in the Tagliamento and Brenta Rivers, respectively. Up to 713 and 1610 grains were surveyed from a single coloured area in the Tagliamento and Brenta Rivers, respectively. Coloured particles were found as far as $142.5 \mathrm{~m}$ and $104.0 \mathrm{~m}$ from the spray-painted areas in the case of the Tagliamento and Brenta Rivers, respectively. The mean displacement length of coloured particles (irrespective of their size) appears to be correlated with the dimensionless shear stress $(R=0.708)$, and values obtained from the two rivers are significantly similar (one-way ANCOVA test $F=30.19$; $P>0.01$ ) and follow the same trend (Figure 10).

Values of displacement lengths were used to calculate the virtual velocity of marked particles. The displacement length was divided by the duration of the flow with dimensionless shear stress between the thresholds identified in the field as significant for determining partial transport conditions (i.e. 0.02 and 0.04). As first proposed by Hassan et al. (1992), the velocity of particles is called virtual because it incorporates periods of both motion and rest, and it is thus very likely to underestimate the actual velocity of particles during flood events. The value of calculated virtual velocities ranges from 0.026 to $3.2 \mathrm{~m} \mathrm{~h}^{-1}$ and, despite a certain scatter [mean $=0.664 \mathrm{~m} \mathrm{~h}^{-1}$; standard deviation $(\mathrm{SD})=0.733 \mathrm{~m} \mathrm{~h}^{-1}$ ], the virtual velocity is positively correlated with the dimensionless shear stress (Figure 10; $R=0.668$ ), and values obtained from the two rivers are significantly similar (one-way ANCOVA test $F=24.19 ; P>0.01$ ). 

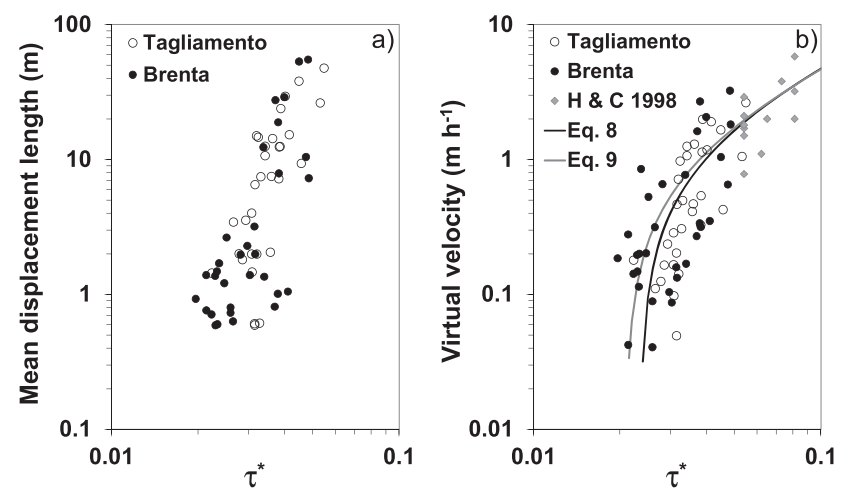

Figure 10. Mean displacement lengths (a) and virtual velocity (b) of coloured particles featuring partial transport conditions as a function of the dimensionless shear stress. Virtual velocity data obtained by Haschenburger and Church (1998) is plotted as well.

Also, the obtained values are reasonably comparable with those obtained by Haschenburger and Church (1998) in the Carnation Creek. Expressing the virtual velocity in $\mathrm{m} \mathrm{s}^{-1}$, the empirical regressions (Equations 8 and 9 for the Tagliamento and Brenta Rivers, respectively) are:

$$
V=-1.450+61.742 \tau^{*} \quad\left(R^{2}=0.504 ; P<0.001 ;\right.
$$

$$
\text { SE of the estimate }=0.47 \mathrm{~m} \mathrm{~s}^{-1} \text { ) }
$$

$$
\begin{gathered}
V=-1.235+59.009 \tau^{*} \quad\left(R^{2}=0.403 ; P<0.001 ;\right. \\
\text { SE of the estimate } \left.=0.63 \mathrm{~m} \mathrm{~s}^{-1}\right)
\end{gathered}
$$

Tracers that moved downstream from coloured areas ranged from 1.4 to $160 \mathrm{~mm}$ in size, but only sediments coarser than $4 \mathrm{~mm}$ were considered to derive the regressions. The mean displacement lengths of each half-phi grain sized class for each of the coloured areas that featured partial transport are plotted in

F11Figure 11. Despite the scattered pattern of mean displacement length of sediments of different sizes, partially due to the different number of particles for each class that moved and were recovered, systematic trends can be recognized on data collected on both rivers (Figure 11). Along with the expected increase of mean displacement length with the dimensionless shear stress, Figure 11 shows that displacement lengths tend to decrease with increasing grain size, at least at the highest shear stresses. At low shear stresses, only fine sediments moved for less than a few metres. Also, the displacement length tends to be insensitive to the size of these sediments. However, for higher shear stresses the coarser particles tend to be transported far less than finer fractions.
If dimensionless terms are used for scaling both grain size (using the median diameter $D_{50}$ ) and the displacement lengths (using the mean transport distance of the size equal to $D_{50}$ ), data collapsed quite well on previously reported trend (e.g. Church and Hassan, 1992), even if systematically displaced towards coarser grain sizes, likely due to the fact that the relationship of Church and Hassan (1992) was scaled using the subsurface rather than the surface $D_{50}$ as in the present study. The convex-up trend shown on Figure 12 confirms that the F12 mean displacement length reduced rapidly for fractions coarser than the median size, whereas the displacement length of fractions finer than $D_{50}$ is more insensitive to grain size.

Size-dependent mean displacement lengths were used to calculate virtual velocity as a function of both the shear stress and the size of sediments for the case of partial transport. Here the virtual velocity has been calculated as the displacement length divided by the duration of the flow with dimensionless shear stress between 0.02 and 0.04 (Figure 8). As previously suggested (e.g. Ferguson and Wathen, 1998; Milan, 2013), if virtual velocity and grain size are expressed in dimensionless terms $\left[V_{i}^{*}=V_{i}(g D)^{0.5}\right.$, and $\left.D_{i}^{*}=D_{i} / D_{50}\right]$, strong relationships can be defined between virtual velocity and both dimensionless grain size and dimensionless shear stress. The empirical regressions obtained for the Tagliamento and Brenta Rivers (Equations 10 and 11, respectively) are as follows:

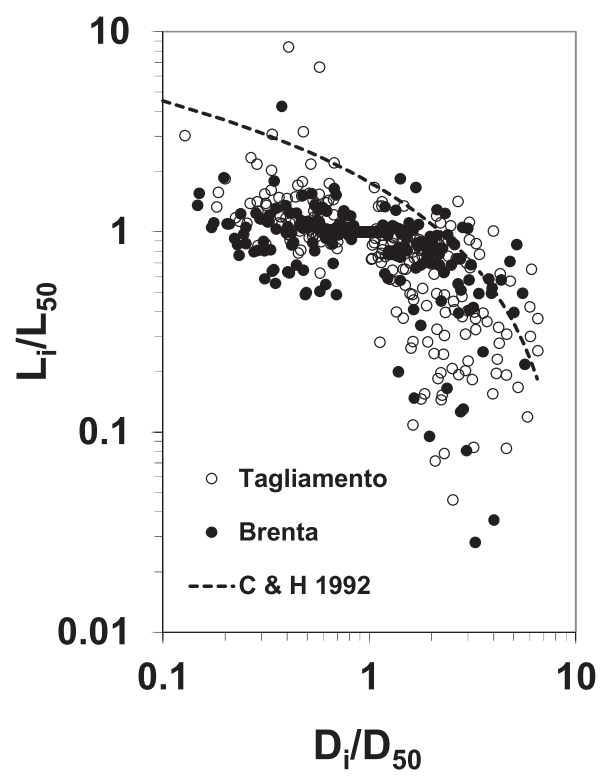

Figure 12. Scaled mean displacement length as a function of scaled grain size. The empirical relation of Church and Hassan (1992) is plotted as well.
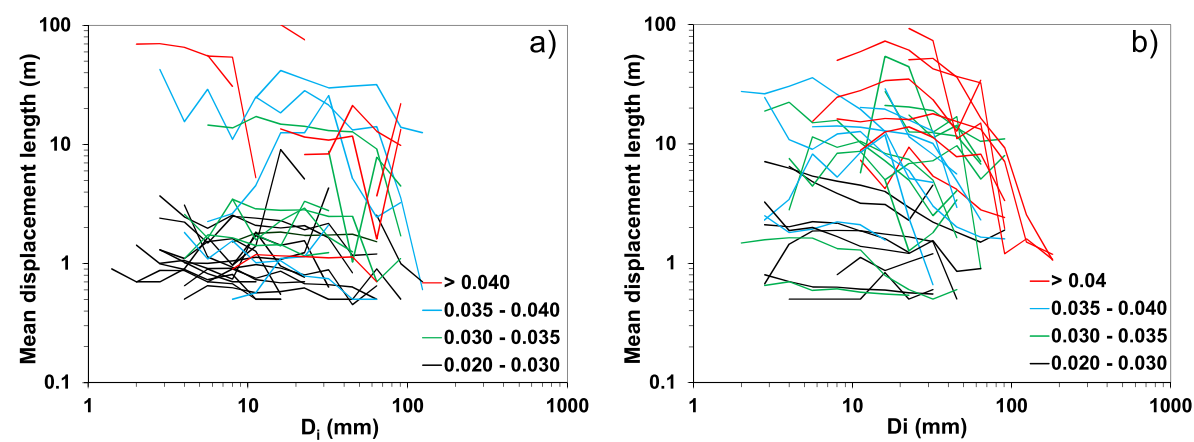

Figure 11. Mean displacement length of particles of different size for each coloured area where evidence of partial transport was recognized in the Tagliamento (a) and Brenta Rivers (b). Each series represents a coloured area, which is identified by the dimensionless shear stress. 
$\log V^{*}=-4.56-0.42 D_{i}^{*}+36.55 \tau^{*}$

$$
\left(R^{2}=0.398 ; P<0.001\right)
$$

$$
\begin{array}{r}
\log V^{*}=-4.56-0.24 D_{i}^{*}+35.39 \tau^{*} \\
\left(R^{2}=0.316 ; P<0.001\right)
\end{array}
$$

If virtual velocity is expressed as $\mathrm{m} \mathrm{h}^{-1}$, the empirical regressions obtained for the Tagliamento and Brenta Rivers (Equations 12 and 13, respectively), which have found to be significantly similar (one-way ANCOVA test $F=38.48$; $P>0.01)$, are:

$$
\begin{aligned}
V i= & -0.0008-0.01685 D_{i}+0.0467 \tau^{*} \\
& \left(R^{2}=0.274 ; P<0.001 ; \mathrm{SE} \text { of the estimate }=0.27 \mathrm{~m} \mathrm{~s}^{-1}\right)
\end{aligned}
$$

$$
\begin{aligned}
V i= & -0.0008-0.0082 D_{i}+0.04915 \tau^{*} \\
& \left(R^{2}=0.236 ; P<0.001 ; \text { SE of the estimate }=0.17 \mathrm{~m} \mathrm{~s}^{-1}\right)
\end{aligned}
$$

\section{Shear stress and the extent of partial transport}

F13Figure 13 shows that the fraction of mobilized sediments from the surface layer $Y$ increases with the shear stress acting on the bed, and the best-fit regression among those tested reads as follows:

$$
Y=2.232+\left(0.475 \log \tau^{*}\right)
$$

The equation is statistically significant at $P<0.01$, its coefficient of determination is $R^{2}=0.353$, and the SE of the estimates is 0.19 . The considerable scatter on the data shown on Figure 13 can be due to differences in grain size among the coloured areas, and to a range of field issues such as staining of the sediments, overturn of sediments due to wind or rain splash, or partial deposition of sand over the coloured areas, all of which are difficult to assess. Despite these potential sources of errors, Equation 14 provides an estimate of the proportion of the surface mobilized over the duration of over threshold flows, which would be otherwise very challenging to obtain in the field.

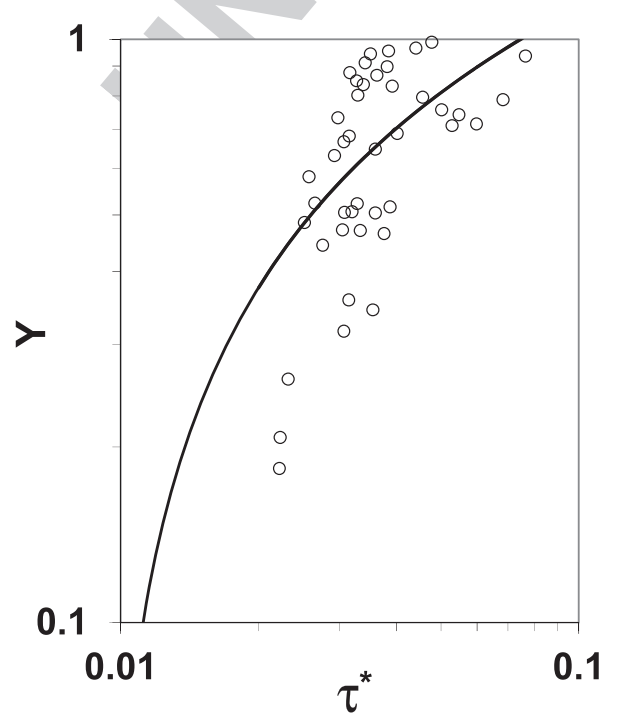

Figure 13. Extent of partial transport $(Y)$ versus dimensionless shear stress in the Tagliamento River. Equation 14 is also plotted.
Bed material transport assessment using the virtual velocity approach

The local $\tau^{*}$ was used in order to distinguish the portions of the cross-sections where partial or full transport occurred (Figure 8 ). The application of the virtual velocity method provided values of fractional transport rates as a function of $\tau^{*}$. It is interesting to note the rate of bed material transport and compare this with the transport rates provided by the traditional formulas. Figure 14 shows the transport rates obtained for the median F14 grain size. As partial transport was found to begin at a shear stress of approximately 0.02 , it appears that bed material load occurs as partial transport at values of under-threshold shear stress, for which the traditional formulas (that adopt 0.056 as threshold) do not account for sediment transport. Instead, at shear stresses higher than the Shields threshold, the rate at which transport rate increases with shear stress is lower than predicted using the traditional formulas.

When applied to the flood events that occurred during the study period, the virtual velocity method provides values that range depending on the magnitude and duration of floods, but also local $D_{50}$ and geometry of the cross-section. Figure 15 shows the volumetric estimate of bed sediment trans- F15 port for the analysed floods. Volumes are presented along with the uncertainty due to the errors in estimates of virtual velocity, active thickness of sediments, and extent of partial transport. Here we assume that these errors are independent and that other potential sources of errors are negligible in comparison with these. Uncertainty associated to each variable is determined using the SEs. Because the variables are multiplied (see Equations 2, 3, and 4), the errors can be added in quadrature (i.e. errors are combined by squaring, adding, and then taking the square root), as done previously in other estimations of bed sediment transport (e.g. Haschenburger and Church, 1998). The uncertainty in the estimation of volumes transported as partial transport is around $31.4 \%$ and $36.3 \%$ for the Brenta and Tagliamento Rivers, respectively, whereas the uncertainly in the estimation of volumes transported as full mobility is around $69.3 \%$ and $52.1 \%$ for the Brenta and Tagliamento Rivers, respectively. The higher uncertainly in the estimation of full transport is mainly due to the higher SEs associated with the vir-

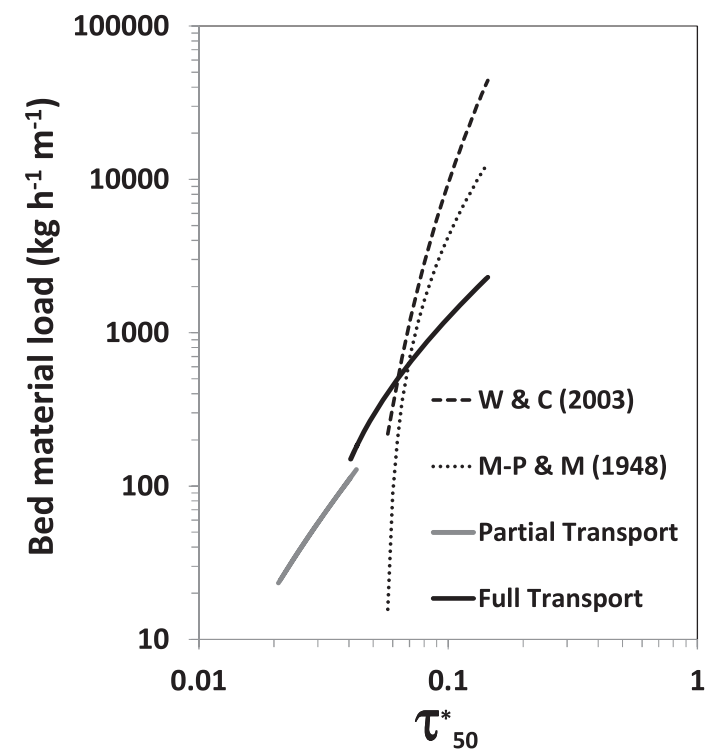

Figure 14. Sediment transport rates as a function of the dimensionless shear stress, as it results from the application of Equation 2 for the case of partial and full transport conditions. Meyer-Peter and Müller (1948) and Wilcock and Crowe (2003) formulas are plotted as well. 

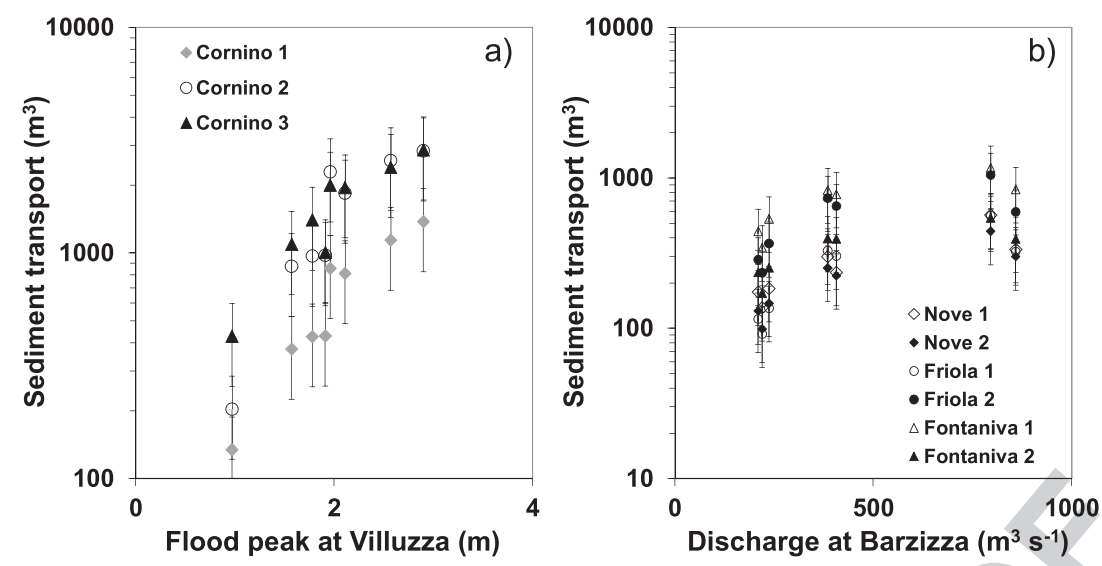

Figure 15. Sediment load volumes calculated for all analysed floods on the Tagliamento (a) and Brenta Rivers (b).

tual velocity. Overall, in the final calculated volumes, the uncertainty around the estimated values are around $38 \%$ and $43 \%$ for the Brenta and Tagliamento Rivers, respectively.

For the lowest flood that occurred on the Tagliamento River during the study period (28 May 2011), a total volume of 134 $\pm 51 \mathrm{~m}^{3}$ of bed material transport has been calculated for the cross-section Cornino 1, of which approximately $70 \%$ was due to partial transport, and the rest as full transport

F16(Figure 16). As expected, the traditional formulas provide higher volumes of coarse sediment transport by an order of magnitude using Meyer-Peter and Müller (1948) $\left(3157 \mathrm{~m}^{3}\right)$, and Wilcock and Crowe (2003) $\left(3448 \mathrm{~m}^{3}\right)$ equations. Interestingly, if the highest flood is considered (1 November 2011), partial transport contributes with only $38 \%$ of the overall calculated transport of around $1378 \pm 603 \mathrm{~m}^{3}$. The difference between rates calculated using the virtual velocity approach and the traditional formula increases at the highest shear stresses, total coarse sediment transport is overestimated by nearly two orders of magnitude using Meyer-Peter and Müller (1948) (144 $\left.225 \mathrm{~m}^{3}\right)$, and Wilcock and Crowe (2003) (383 $737 \mathrm{~m}^{3}$ ) equations.

It is worth noting the spatial variations in bed material load fluxes, and in particular that volumes calculated for Cornino 2 and 3 are always higher than in Cornino 1 (Figure 15). Volumes calculated for the lowest flood (28 May 2011) increase from $134 \pm 51$ in Cornino 1 to $203 \pm 69$ and $427 \pm 152 \mathrm{~m}^{3}$ in Cornino 2 and 3, respectively, and volumes calculated for the highest flood (1 November 2011) increase from $1378 \pm 603$ in Cornino 1 to $2834 \pm 1212$ and $2865 \pm 1244 \mathrm{~m}^{3}$ in Cornino 2 and 3, respectively (Figure 15). These variations could reflect differences in local hydraulic conditions, but spatial variations in braided rivers have been commonly observed and may be also due to river morphodynamics (e.g. bar migration, channel switching) which causes a general tendency for fluxes to be filtered by sediment storage and release over a range of spatial and temporal scales (Ashmore, 2013). Similar differences are evident for the Brenta River, on which calculated bed material load ranges from $115 \pm 36$ to $441 \pm 138 \mathrm{~m}^{3}$ for the lower flood (21 July 2010) in Friola 1 and Fontaniva 1 sections, respectively, and ranges from $299 \pm 151$ to $838 \pm 347 \mathrm{~m}^{3}$ in Nove 2 and Fontaniva 1 sections, respectively (Figure 15).

\section{Discussion}

\section{Morphological effects on painted areas}

On the Tagliamento and Brenta Rivers, at dimensionless shear stress ranging from 0.02 to 0.04 , the gravel bed is likely to experience partial transport, i.e. only a certain percentage of bed particles is entrained. At $\tau^{*}$ higher than approximately 0.04 it is likely that all particles of the bed will be removed or buried, thus being the case of full transport, sensu Haschenburger and Wilcock (2003). Full transport was observed for a very wide range of dimensionless shear stress (from 0.02 up to 0.14 ), probably due to dislodgement of all particles as earlier armour break-up even at low values of shear stress on the one hand (Vericat et al., 2006b), and to very high resistance to particle Q5 dislodgment due to sediment clustering and imbrication on the other hand (Buffington and Montgomery, 1999). Even if critical Shields stress for particle entrainment is generally considered to be around 0.056 (Shields, 1936), recent works
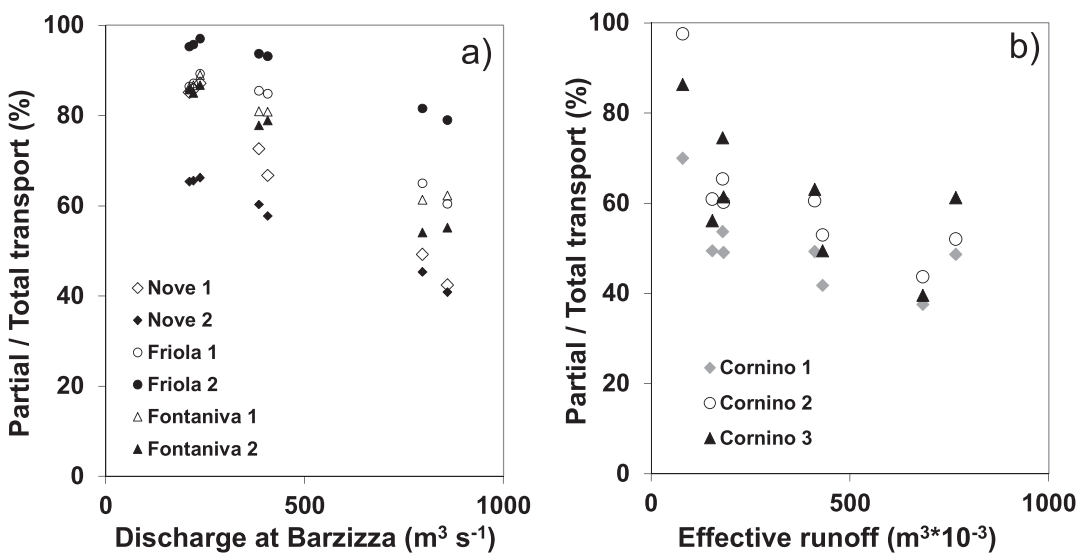

Figure 16. Relative contribution of partial transport to the total bed material transport as a function of the peak of the studied flood events occurred on the Tagliamento (a) and Brenta Rivers (b). 
highlight that the actual value strongly depends on the methods used for identifying it, along with the local conditions of slope, roughness and relative roughness (e.g. Buffington and Montgomery, 1997; Lamb et al., 2008). Mueller et al. (2005) report reference Shields stress for bedload transport for lowgradient gravel-bed rivers ranging from 0.025 to 0.035 , which approximates the range for partial transport identified in the present study. Dimensionless shear stress ranging from 0.04 to 0.05 was identified as a threshold for full transport in gravel-bed rivers also by Snyder et al. (2008). Thresholds just slightly higher are reported by Lisle et al. (2000) for gravelbed rivers in California and Colorado, where the bed was stable for $\tau^{*}<0.03$ ) and experienced partial transport for $0.03<\tau^{*}<0.06$, and full transport for $\tau^{*}>0.06$. However, Lisle et al. (2000) study was based on a comparison between local boundary shear stress as predicted by a numerical model and the measured median surface particle size at bankfull discharge.

The range of shear stress responsible for partial and full transport is very similar between the Tagliamento River and the Brenta River. This is partially due to the fact that the same criterion was used to identify the entrainment classes in the field, but it is remarkable considering that the shear stress was calculated using the local $D_{50}$ and that a wide range of grain sizes, slopes, and water depths were used.

Regarding the thickness of the active layer of sediments, the data collected in the field are widely scattered (Figure 9). This is not surprising, as the thickness of the active layer strongly depends on the local hydraulic conditions, grain size, hiding/protrusion effects, armour ratio, and presence of immobile grains (e.g. Wilcock and McArdell, 1997; Wilcock, 1997; DeVries, 2002; Houbrechts et al., 2012) along with even more challenging parameters to consider, such as the particular sequence of flood events (Haschenburger, 2011). However, data superimpose relatively well with other field evidence obtained by DeVries (2002) in a wide variety of gravel-bed rivers. Also, the empirical regression between shear stress and the thickness of active layer obtained by Wilcock and McArdell (1997) in a series of flume runs using a bimodal grain size distribution, plots within the range of observed values. Both DeVries (2002) and Wilcock and McArdell (1997) suggested relating the local dimensionless shear stress to the scaled fractional exchange depth $\left(d_{x} / D_{90}\right.$ or $\left.d_{x} / D_{50}\right)$. However, this did not improve our regressions, suggesting that other factors are likely more relevant than the local grain size distribution in determining the thickness of the active layer. For example, local hydraulics conditions (Lawless and Robert, 2001), grain imbrication (Qin et al., 2012), grain clusters (Wittenberg and Newson, 2005), and sediment clogging due to fine sediments (Schälchli, 1992) could influence the entrainment of surface grains.

\section{Virtual velocity of sediments}

Tracers showed that the displacement length tends to be insensitive to the size of sediments at low shear stresses, but that displacement length decreases with increasing grain size at the highest shear stresses. This suggests that sediment mobility in the Tagliamento and Brenta Rivers follow a dynamics of equal-mobility transport condition for the finer fractions and size-selectivity transport for the coarsest sediments. This agrees with similar field studies (e.g. Ferguson and Wathen, 1998; Marion and Weirich, 2003; Mao and Lenzi, 2007; Mao and Surian, 2010). Flume observations made by Wilcock (1997) further reported displacement lengths independent of grain size for fine, mobile sizes, and decreasing displacement length for larger fractions.

In the Tagliamento and Brenta Rivers, the virtual velocity of coloured particles is a function of their size, the median grain size of the area in which they are lying, and the driving force for entrainment and transport, expressed in terms of shear stress. The relatively low coefficients of determination for Equations 12 and 13 could be due to errors and uncertainties related to variables measured in the field, and to the lack of representation of other physical controls over the entrainment phenomena. Also, methodological issues could be related to the use of the Digital Gravelometer (Graham et al., 2005, 2010) to quantify the local $D_{50}$, even if Mao and Surian (2010) used it successfully in the Tagliamento River, observing errors to be around $10 \%$ for the $D_{50}$. Even if comparisons of manual and photograph-derived area-by-number samples have previously proved that the software can be an effective way of quantify the local grain size (e.g. Graham et al., 2005, 2010; Chinello, 2006), issues remain on errors related to partial burial Q6 or imbrication of the coarsest grains, effects due to sand covering gravel particles, or the effects of the speckled nature of the coarsest particles, which can lead to over-fragmentation during the automatic photograph analysis. Apart from issues related to the field methods, questions arises on the effectiveness of using only the $D_{i} / D_{50}$ factor for expressing the hiding and protrusion effects, and to the fact that surface roughness, imbrication, and orientation at the grain and cluster scales, are not considered. Terrestrial laser scanners have already proved able to quantify grain size, roughness, and complexity (e.g. Hodge et al., 2009; Picco et al., 2013; Baewert et al., 2013), and could represent a valid alternative for characterizing the local controls on sediment entrainment and transport. Despite all the biases and limits recognized, Equations 12 and 13 are likely to represent the best way of expressing the dependence of virtual velocity on shear stress and grain size in the two study sites.

\section{The extent of partial transport}

Along with the observation that the traditional formulas provide higher volumes of coarse sediment transport if compared with the virtual velocity method, it seems worth stressing here the role that partial transport appears to play during events of different magnitude. Because the cross-sections of the Tagliamento and Brenta Rivers are very wide, during ordinary events the channel bed is likely to be flooded with shallow water depths over bars and secondary channels. This generates low shear stresses that lead to partial transport conditions for relatively long periods and over large areas. For this reason, partial transport is particularly important during low magnitude events. The relative contribution of partial to the total sediment transport decreases with the magnitude of the flood peak (Figure 16). Partial transport represents around $50-70 \%$ of the total bed material load for a flood of approximately a third of bankfull event in the Tagliamento River, and this relative contribution decreases to $20-30 \%$ for a near-bankfull event. Because the use of the flood peak could be misleading in evaluating the magnitude of a flood, the effective runoff of the events has been calculated (see Table I), and this progressive decrease of partial transport contribution to total coarse material load appears to be confirmed. This corroborates the earlier observation of Haschenburger and Wilcock (2003) that, even if unable to assess the contribution of partial transport to the overall transport volume, it was evident that the percentage of bed in a state of partial mobility decreased from $60 \%$ to $25-50 \%$ under floods of half-bankfull to bankfull conditions, respectively. The differences in relative importance of partial transport 
between the three cross-sections of the Tagliamento River (Figure 16) are likely due to their geometry. In fact, Cornino 1 features a large island on its left side (see Figure 2) that reduces the overall width/depth ratio, leading to higher shear stresses than Cornino 3, which features a wider and shallower main channel as well. Evidence provided by coarse sediment load calculations on the Brenta River is comparable with what observed in the Tagliamento River. The relative importance of partial transport is lower in the Nove reach, which is relatively narrow (mainly due to artificial rip-raps and longitudinal defences, Moretto et al., 2014), but dominates, especially during low-magnitude events in the cross-sections of the Friola reach, which are much wider.

\section{Annual sediment yield in the Tagliamento and Brenta Rivers}

The virtual velocity approach was also used to calculate the annual bed material yield in the Tagliamento and the Brenta Rivers. Calculations were performed using the daily averaged values of water stage measured in 2010 (a year with a high number of formative events, see Surian et al., 2015) at Villuzza and Barzizza, respectively. In the Tagliamento River, the sediment yield ranges from $80 \pm 30 \times 10^{3} \mathrm{~m}^{3} \mathrm{yr}^{-1}$ calculated at Cornino 1 , of which $10 \%$ is partial transport, to 155 $\pm 60 \times 10^{3} \mathrm{~m}^{3} \mathrm{yr}^{-1}$ calculated at Cornino 3 , of which $17 \%$ is partial transport. Likewise, in the Brenta River, the sediment yield ranges from $11 \pm 4$ to $32 \pm 13 \times 10^{3} \mathrm{~m}^{3} \mathrm{yr}^{-1}$ if calculated at Friola 1 and Fontaniva 1, of which $12 \%$ is partial transport. Bedload formulas would thus provide higher estimate of sediment yield by more than an order of magnitude in both the Tagliamento and Brenta Rivers.

Previous estimates of sediment yield in the Tagliamento River were obtained using a reduced-complexity numerical model (CAESAR), and provided mean volumes of $60 \times 10^{3} \mathrm{~m}^{3} \mathrm{yr}^{-1}$ for the period 2001-2009, with a range of $10 \times 10^{3} \mathrm{~m}^{3} \mathrm{yr}^{-1}$ (in 2005) to $200\left[10^{3} \mathrm{~m}^{3} \mathrm{yr}^{-1}\right.$ (in 2002) (Ziliani et al., 2013), thus comparable with the value calculated using the virtual velocity approach (i.e. from 80 to $150 \times 10^{3} \mathrm{~m}^{3} \mathrm{yr}^{-1}$ ). For the Brenta River, Surian and Cisotto (2007) estimated sediment yield from $10 \times 10^{3} \mathrm{~m}^{3} \mathrm{yr}^{-1}$ up to $70 \times 10^{3} \mathrm{~m}^{3} \mathrm{yr}^{-1}$ by using a morphological method based on the assessment of erosion and deposition volumes for the period 1984-1997. Again, these values are of the same order of magnitude of those calculated in this study.

Overall, the coarse sediment yields obtained in the present study are comparable with estimates on wide gravel-bed rivers obtained through morphological methods. For example, for the Waimakariri River (New Zealand), which is quite comparable with the Tagliamento River in terms of basin area, slope,

Q7 grain size and width, Carson and Griffiths (1989) used morphological changes measured at the Crossbank reach to estimate annual bed material load, quantified as being around $154 \times 10^{3} \mathrm{~m}^{3} \mathrm{yr}^{-1}$. A similar bed material load was obtained

Q8 through numerical modelling by Nicholas (1999), who was also able to highlight the importance of relatively low discharges in the annual sediment transport in braided rivers. Similar volumes were obtained in other gravel bed rivers using morphological methods. For example, Ham and Church (2000) reported $5-55 \times 10^{3} \mathrm{~m}^{3} \mathrm{yr}^{-1}$, for the Chilliwack River, gravel bed river draining a $1230 \mathrm{~km}^{2}$ basin in which they estimated bed material transport rates using a sediment budget approach in a $49 \mathrm{~km}$-long reach of the Chilliwack River, downstream of a lake, which was considered to block sediment transfers from upstream reaches. However, only the lower portion of the study reach was braided and comparable with our study rivers (slope $=0.006 \mathrm{~m} \mathrm{~m}^{-1}, D_{50}=32 \mathrm{~mm}$ ), and the approach is not directly applicable in the Tagliamento and Brenta Rivers, because of the lack of natural (lakes) or anthropogenic (reservoirs) discontinuities that can be assumed to trap the whole amount of sediments transported from upstream reaches. Another application of the morphological method for the estimation of bedload in a large gravel bed river is the study of Martin and Church (1995) who calculated $27-157 \times 10^{3} \mathrm{~m}^{3} \mathrm{yr}^{-1}$ for the Vedder River. The Vedder River in their study section drains $1230 \mathrm{~km}^{2}$ and the flood regime is comparable to that featured by the Tagliamento and Brenta Rivers, with high flows in autumn and winter, and snowmelt floods in spring. Again, the calculated bed material transport volumes are relatively comparable with that obtained in the present study for the Tagliamento and Brenta Rivers, but the study was conducted in a long segment, where morphology ranges from being cobble-bed and confined to gravel-bed and $700 \mathrm{~m}$ in a wide braided reach. Also, the estimation of bed material transport is based on a sediment budget approach assessed by analysing the changes in area for 49 cross-sections, assuming zero transport rate in a certain cross-section. However, it is interesting to report that in a following study Martin (2003) applied the Bagnold and Meyer-Peter and Müller formulas on the same reach, showing that the formulae tended to underpredict gravel transport rates, probably due to dredging activities that might have loosened the bed structure.

\section{Limitations, further improvements, and potentials of the method}

The virtual velocity method proved to be a relatively inexpensive way to provide valuable insights on sediment mobility and reasonable estimates of bed material yield for wide gravel-bed rivers, on which direct sampling during floods would be unfeasible. However, comparisons are usually done with volumes obtained using morphological methods, which provide reasonably robust estimates of the time- and spaceaveraged sediment yield (Ashmore and Church, 1998; Hicks and Gomez, 2003), but are based on many assumptions, the most important of which is that the sediment transport should be known at a given cross-section (McLean and Church, 1999; Surian and Cisotto, 2007).

The virtual velocity method provides local evidence of sediment mobility and allows estimation of bed material yield, but it appears hampered by some limitations. First, the method proved to be relatively time-consuming for field surveys, as one-day/two-person survey was generally needed for postevent topographical surveys and post-event collection and measurements of transported sediments on each cross-section. In addition, the empirical relationships between shear stress and the thickness of the active layer, virtual velocity, and extent of partial transport proved to be relatively weak. This adds uncertainty to the final estimation of coarse sediment yield, which has been estimated around $40 \%$. However, errors in bedload predictions could be comparable if one would attempt to calculate bedload at the cross-section scale based on a few bedload samplings, and bedload predictions using formulas are known to range within one or more order of magnitude from observed rates (e.g. Barry et al., 2004).

Another limitation of the approach is that sediments finer than $4 \mathrm{~mm}$ have not been considered in the calculations. Even if fine gravel and sand can represent an important component of sediment yield in gravel-bed rivers (e.g. Grams and Wilcock, 
2014) they are usually not measured in gravel-bed rivers. For example Bunte's type bedload traps are used to collect particles larger than $4 \mathrm{~mm}$ in size (e.g. Bunte et al., 2008). Using geophones and similar surrogate bedload monitoring devices, the minimum particle size detectable for impact counts is not finer than $10 \mathrm{~mm}$ (e.g. Rickenmann et al., 2014).

In the theoretical framework provided by Wilcock (1997), the extent of partial transport $Y$ was in fact $Y_{i}$, because it was defined as the proportion of grains of fraction $i$ entrained from the surface. In the present study, we could assess only the percentage of bed surface that remained immobile, considering it as a proxy for the degree of partial transport. In future field studies, it could be possible to quantify the relationship between $Y_{i}$ and flow strength, by comparing the number of clasts recovered and the number of clasts of the same size painted in each area. This could be done when more advanced photographic methods for identifying single grains in a bed surface automatically would be available and fully operative (e.g. Bianconi et al., 2015). However, it is not clear how using $Y_{i}$ rather than $Y$ could improve substantially the accuracy of sediment yield. Furthermore, a study of this kind could be accomplished only using a large number of individual tracers deployed in many portions of the cross-section, and taking care of emplace tracers in the bed mimicking the natural surface arrangement of sediments. Also, the weakness of Equation 14, suggests that a considerable number of field data should be necessary to derive a reliable relationship between shear stress and $Y_{i}$. Part of the issue related with our approach to assess $Y$ is that sediments covering immobile coloured sediments could provide misleading evidence of partial transport (see for instance Figure 5a). Also, sediments finer than $4 \mathrm{~mm}$, which corresponds to the lower truncation of grain size distribution curves derived from the photographs, were coloured in the sampling areas, but are not considered in the calculation of bed material load. However, the percentage of fine sediments $(<4 \mathrm{~mm})$ in the surface was always low, as areas to be coloured were selected avoiding portion of bars with significant presence of sand.

In the present study we could survey over a wide range of shear stresses and flood magnitudes in both the Tagliamento and Brenta Rivers, as the maximum recurrence interval of flood events was of 2.2 and 10 years, respectively. It is unlikely that higher-magnitude floods could have been explored, due to the probable disappearance of tracers from the maximum displacement length available for tracers, which depends on the length of bars. Also, with more severe floods, more channel avulsion would have occurred, which would have hampered the application of the virtual velocity method, as this cannot account for mass movements such as bank erosion and bar migration.

In calculating bed material transport using the virtual velocity approach, we have used cross-section averaged values of grain size. Future improvements should consider using local grain size as derived from photographic methods. These photographs should be taken after each explored flood event, on a wide range of featured morphological units, elevations relative to the main channel, and dominant grain size. Also, a terrestrial laser scanner could be used to assess local roughness and grain size in a non-destructive manner (e.g. Hodge et al., 2009), as also demonstrated in the Tagliamento River (e.g. Picco et al., 2013).

Although painting particles proved inexpensive and allowed for following the movements of a high number of potential tracers at a considerable amount of sites along the crosssections, it is worth pointing out that recent improvements in the use of passive integrated transponders (PITs; Bradley and Tucker, 2012; Chapuis et al., 2014) and motion-sensing radio tags (May and Pryor, 2014) could prove useful for tracking tracers over longer distances without having to pick them up. Besides, transponders permit the identification of buried particles. Although PIT tags have been mainly used in small and narrow channels, some experience on wide gravel bed-rivers has already been gained (e.g. Houbrechts et al., 2012; Chapuis et al., 2015) and in the Tagliamento River have preliminary proven to be a valuable alternative or complementary approach to coloured particles. Still, special care should be used in deploying PIT tags, as one should avoid disturbing the surface sediments, and should also replace local grains of the same size in order to maintain clusters and local conditions of imbrication. Also, it should be stressed that the coloured area approach that we used in this study allowed to assess mobility of particles as fine as $4 \mathrm{~mm}$, whereas PIT tags used in the field are generally installed in particles coarser than $20 \mathrm{~mm}$.

For future applications of this method, we would suggest the use of local water stage sensors, in order to avoid the delicate process of developing an empirical relationship between local water stage and data collected at a nearby gauging station, thus estimating more precisely the shear stresses and the duration of above-threshold flows.

Even if the application required a considerable amount of field surveys, it is envisaged that only a few field observations at low flow could help calibrating available empirical formulas of virtual velocity (e.g. Milan, 2013) and thickness of active sediments (e.g. Houbrechts et al., 2012) in order to provide a better combination of accuracy and effort in sediment load assessment. As to the assessment of the sources and propagation of errors, the approach used in this paper could be further improved by applying a more sophisticated approach such as the Bayesian method, successfully tested by Schmelter et al. (2011, 2012.

\section{Conclusions}

This work represents the first attempt to use the virtual velocity approach to assess sediment mobility and bed material transport in wide and complex gravel-bed rivers. The field method involved the use of spray-painted areas, scour chains on various portions of several cross-sections, and resurveys of crosssections after significant flood events. Field data enabled empirical ranges of dimensionless shear stresses at which partial and full transport occurred, and then relationships between dimensionless shear stress and thickness of active sediments, extent of partial transport, and virtual velocity under partial and full transport conditions. The mean displacement length of particle, the thickness of the active layer and the extent of partial transport are well correlated with dimensionless shear stress. Robust relationships were also defined between dimensionless virtual velocity and both dimensionless grain size and shear stress.

The virtual velocity approach was used to calculate bed material transport for a wide range of flood magnitudes. Annual bed material load was calculated up to 150 and $30 \times 10^{3} \mathrm{~m}^{3} \mathrm{yr}^{-1}$ for the Tagliamento and Brenta Rivers, respectively. The outcomes of this work highlight the relevance of partial transport condition, as it can represent more than $70 \%$ of the total coarse sediment transported by lowmagnitude floods, and up to $40 \%$ for near-bankfull events. Also, results show that, as expected, sediment transport tends to be overestimated by traditional formulas.

Considering that either direct samplings or indirect surrogate methods are not feasible in wide gravel-bed rivers, this first application of the virtual velocity approach in such rivers is promising, as it proved to be a useful method to estimate sediment mobility and load transport during floods. The method is believed to perform particularly well during ordinary low- 
magnitude flood events, when major morphological changes such as channel migrations are less likely to occur.

Acknowledgements - This research was supported by funds from the Fondazione CARIPARO project 'Linking geomorphological processes and vegetation dynamics in gravel bed rivers'; the National Italy Research Project 'National network for monitoring, modeling and sustainable management of erosion processes in agricultural land and hillymountainous area' $N^{\circ}$ 20104ALME4-2013-15; and by the Project 'SedAlp: sediment management in Alpine basins, integrating sediment continuum, risk mitigation and hydropower', 83-4-3-AT-2012-2015. The authors thank Francesco Comiti, Emanuel Rigon, Paolo Vitti, Bruno Garniga, Bruno Golfieri and Diego Ravazzolo who were involved in planning the research and helped in the field.

\section{Q11 References}

Ashmore P. 2013. Morphology and dynamics of braided rivers. In Treatise on Geomorphology, Shroder I (ed). Academic Press: London; 289-312.

Ashmore P, Church M. 1998. Sediment transport and river morphology: a paradigm for study. In Gravel-bed Rivers in the Environment (Proceedings volume of the 4th International Workshop on Gravel-bed Rivers, Gold Bar, Washington, August, 1995), Klingeman P, Beschta RL, Komar P, Bradley J (eds). Water Resources Publications: Highlands Ranch, CO; 115-148.

Baewert H, Bimböse M, Bryk A, Rascher E, Schmidt K, Morche D. 2013. Roughness determination of coarse grained alpine river bed surfaces using terrestrial laser scanning data. Zeitschrift für Geomorphologie 58(1): 81-95.

Belleudy P, Valette A, Graff B. 2010. Passive hydrophone monitoring of bedload in river beds: first trials of signal spectral analysis. In Bedload-surrogate Monitoring Technologies, Gray JR, Laronne JB, Marr JDG (eds). US Geological Survey Scientific Investigations Report. US Geological Survey: Reston, VA; 5091.

Bertoldi W, Zanoni L, Tubino M. 2010. Assessment of morphological changes induced by flow and flood pulses in a gravel bed braided river: the Tagliamento River (Italy). Geomorphology 114: 348-360. DOI:10.1016/j.geomorph.2009.07.017.

Bianconi F, Di Maria F, Micale C, Fernández A, Harvey RW. 2015. Grain-size assessment of fine and coarse aggregates through bipolar area morphology. Machine Vision and Applications 26: 775-789. DOI:10.1007/s00138-015-0692-z.

Bradley ND, Tucker GE. 2012. Measuring gravel transport and dispersion in a mountain river using passive radio tracers. Earth Surface Processes and Landforms 37: 1034-1045. DOI:10.1002/esp.3223.

Bunte K, Abt SR, Potyondy J, Ryan S. 2004. Measurement of coarse gravel and cobble transport using portable bedload traps. Journal of Hydraulic Engineering 130(9); 879-893. DOI:10.1061//(ASCE) 0733-9429(2004)130:9(879).

Bunte K, Abt SR, Potyondy JP, Swingle KW. 2008. A comparison of coarse bedload transport measured with bedload traps and HelleySmith samplers. Geodinamica Acta 21(1-2): 53-66. DOI:10.3166/ ga.21.53-66

Bunte K, Swingle KW, Abt SR. 2007. Guidelines for using bedload traps in coarse-bedded mountain streams: construction, installation, operation and sample processing. US Department of Agriculture, Forest Service, Rocky Mountain Research Station: Fort Collins, CO.

Buffington JM, Montgomery DR. 1997. A systematic analysis of eight decades of incipient motion studies, with special reference to gravel bedded rivers. Water Resources Research 33(8): 1993-2029. DOI:10.1029/96WR03190.

Buffington JM, Montgomery DR. 1999. Effects of hydraulic roughness on surface textures of gravel-bed rivers. Water Resources Research 35: 3507-3521. DOI:10.1029/1999WR900138.

Chapuis M, Bright CJ, Hufnagel J, MacVicar B. 2014. Detection ranges and uncertainty of passive radio frequency identification (RFID) transponders for sediment tracking in gravel rivers and coastal environments. Earth Surface Processes and Landforms 39: 2109-2120. DOI:10.1002/esp.3620.

Chapuis M, Dufour S, Provansal M, Couvert B, de Linares M. 2015. Coupling channel evolution monitoring and RFID tracking in a large, wandering, gravel-bed river: insights into sediment routing on geomorphic continuity through a riffle-pool sequence. Geomorphology 231: 258-269. DOI:10.1016/j.geomorph.2014.12.013.

Church M, Hassan MA. 1992. Size and distance of travel of unconstrained clasts on a streambed. Water Resources Research 28(1): 299-303. DOI:10.1029/91WR02523.

DeVries PE. 2002. Bedload layer thickness and disturbance depth in gravel bed streams. Journal of Hydraulic Engineering 128(11): 983-991. DOI:10.1061//(ASCE)0733-9429(2002)128:11(983).

Emmett WW. 1980. A Field Calibration of the Sediment-trapping Characteristics of the Helley-Smith Bedload Sampler, US Geological Survey, Professional Paper, vol. 1139. US Geological Survey: Reston, $\mathrm{VA} ; 44$.

Ferguson RI, Wathen SJ. 1998. Tracer-pebble movement along a concave river profile: virtual velocity in relation to grain size and shear stress. Water Resources Research 34: 2031-2038.

Graham DJ, Rice SP, Reid I. 2005. A transferable method for the automated grain sizing of river gravels. Water Resources Research 41(7): W07020. DOI:10.1029/2004WR003868.

Graham DJ, Rollet AJ, Piégay H, Rice SP. 2010. Maximizing the accuracy of image-based surface sediment sampling techniques. Water Resources Research 46: W02508. DOI:10.1029/2008WR006940.

Habersack H, Seitz H, Liedermann M. 2010. Integrative automatic bedload transport monitoring. In Bedload-surrogate Monitoring Technologies. In US Geological Survey Scientific Investigations Report 2010-5091, Gray JR, Laronne JB, Marr JDG (eds). US Geological Survey: Reston, VA; 218-235.

Ham DG, Church M. 2000. Bed-material transport estimated from channel morphodynamics: Chilliwack River, British Columbia. Earth Surface Processes and Landforms 25(10): 1123-1142. DOI:10.1002/ 1096-9837(200009)25:10<1123::AID-ESP122>3.0.CO;2-9.

Haschenburger JK. 1999. A probability model of scour and fill depths in Q12 gravel bed channels. Water Resources Research 35: 2857-2869. DOI:10.1029/1999WR900153.

Haschenburger JK. 2011. Vertical mixing of gravel over a long flood series. Earth Surface Processes and Landforms 36: 1044-1058. DOI:10.1002/esp.2130.

Haschenburger JK, Church M. 1998. Bed material transport estimated from the virtual velocity of sediment. Earth Surface Processes and Landforms 23: 791-808. DOI:10.1002/(SICI)1096-9837(199809) 23:9<791::AID-ESP888>3.0.CO;2-X.

Haschenburger JK, Wilcock PR. 2003. Partial transport in a natural gravel bed channel. Water Resources Research 39: 1020. DOI:10.1029/2002WR001532.

Hassan MA, Church M, Ashworth PJ. 1992. Virtual rate and mean distance of travel of individual clasts in gravel bed channels. Earth Surface Processes and Landforms 17: 617-627. DOI:10.1002/ esp.3290170607.

Hicks DM, Gomez B. 2003. Sediment transport. In Tools in Fluvial Geomorphology, Kondolf GM, Piégay H (eds). John Wiley \& Sons: Chichester; 425-461.

Hilldale R, Carpenter W, Goodwiller B, Chambers J, Randle T. 2015. Installation of impact plates to continuously measure bed load: Elwha River, Washington, USA. Journal of Hydraulic Engineering 141(3) 06014023. DOI:10.1061//(ASCE)HY.1943-7900.0000975.

Hodge R, Brasington J, Richards K. 2009. Analysing laser-scanned digital terrain models of gravel bed surfaces: linking morphology to sediment transport processes and hydraulics. Sedimentology 56: 2024-2043. DOI:10.1111/j.1365-3091.2009.01068.x.

Houbrechts G, Van Campenhout J, Levecq Y, Hallot E, Peeters A, Petit F. 2012. Comparison of methods for quantifying active layer dynamics and bedload discharge in armoured gravel-bed rivers. Earth Surface Processes and Landforms 37: 1501-1517. DOI:10.1002/esp.3258.

Kaless G, Mao L, Lenzi MA. 2014. Regime theories in gravel-bed rivers: Q14 models, controlling variables, and applications in disturbed Italian rivers. Hydrological Processes 28: 2348-2360. DOI:10.1002/ hyp. 9775.

Kasprak A, Wheaton J, Ashmore P, Hensleigh J, Peirce S. 2015. The relationship between particle travel distance and channel morphology: results from physical models of braided rivers. Journal of Geophysical Research - Earth Surface 120: 55-74. DOI:10.1002/ 2014JF003310.

Lamb MP, Dietrich WE, Venditti JG. 2008. Is the critical Shields stress for incipient sediment motion dependent on channel-bed slope? 
Journal of Geophysical Research - Earth Surface 113 . DOI:10.1029/ 2007JF000831.F02008

Lane S, Richards K, Chandler J. 1995. Morphological estimation of the time-integrated bed-load transport rate. Water Resources Research 31 (3): 761-772. DOI:10.1029/94WR01726.

Laronne JB, Outhet DN, Carling PA, McCabe TJ. 1994. Scour chain employment in gravel bed rivers. Catena 22: 299-306. DOI:10.1016/ 0341-8162(94)90040-X.

Lawless M, Robert A. 2001. Three-dimensional flow structure around small-scale bedforms in a simulated gravel-bed environment. Earth Surface Processes and Landforms 26: 507-522. DOI:10.1002/ esp. 195.

Liebault F, Laronne JB. 2008. Evaluation of bedload yield in gravel-bed rivers using scour chains and painted tracers: the case of the Esconavette Torrent (southern French Prealps). Geodinamica Acta 21: 23-34. DOI:10.3166/ga.21.23-34.

Lisle TE, Nelson JM, Pitlick J, Madej MA, Barkett BL. 2000. Variability of bed mobility in natural gravel-bed channels and adjustments to sediment load at local and reach scales. Water Resources Research 36: 3743-3755. DOI:10.1029/2000WR900238.

Mao L, Lenzi MA. 2007. Sediment mobility and bedload transport conditions in an alpine stream. Hydrological Processes 21: 1882-1891. DOI:10.1002/hyp.6372.

Mao L, Surian N. 2010. Observations on sediment mobility in a large gravel-bed river. Geomorphology 114(3): 326-337. DOI:10.1016/j. geomorph.2009.07.015.

Marion DA, Weirich FH. 2003. Equal-mobility bed load transport in a small, step-pool channel in the Ouachita Mountains. Geomorphology 55: 139-154. DOI:10.1016/S0169-555X(03)00137-5.

Martin Y. 2003. Evaluation of bed load transport formulae using field evidence from the Vedder River, British Columbia. Geomorphology 53: 75-95. DOI:10.1016/S0169-555X(02)00348-3.

Martin Y, Church M. 1995. Bed-material transport estimated from channel surveys: Vedder River, British Columbia. Earth Surface Processes and Landforms 20(4): 347-361. DOI:10.1002/esp.3290200405.

May CL, Pryor BS. 2014. Initial motion and bedload transport distance determined by particle tracking in a large regulated river. River Research and Applications 30: 508-520. DOI:10.1002/rra.2665.

McLean DG, Church M. 1999. Sediment transport along the Fraser River 2. Estimates based on the long-term budget. Water Resources Research 35: 2549-2559.

Meyer-Peter E, Müller R. 1948. Formulas for bed-load transport. Proceedings of the Second Meeting of the International Association for Hydraulic Structures Research: 39-64.

Milan DJ. 2013. Virtual velocity of tracers in a gravel-bed river using size-based competence duration. Geomorphology 198: 107-114. DOI:10.1016/j.geomorph.2013.05.018.

Moretto J, Rigon E, Mao L, Picco L, Delai F, Lenzi MA. 2014. Channel adjustments and vegetation cover dynamics in the Brenta River (Italy) over the last 30 years. River Research and Applications 30: 719-732. DOI:10.1002/rra.2676.

Mueller ER, Pitlick J, Nelson JM. 2005. Variation in the reference Shields stress for bed load transport in gravel-bed streams and rivers. Water Resources Research 41: W04006. DOI:10.1029/ 2004WR003692.

Picco L, Mao L, Cavalli M, Buzzi E, Rainato R, Lenzi MA. 2013. Evaluating short-term morphological changes in a gravel-bed braided river using terrestrial laser scanner. Geomorphology 201: 323-334. DOl:10.1016/j.geomorph.2013.07.007.

Qin J, Zhong D, Wang G, Leung S. 2012. On characterization of the imbrication of armored gravel surfaces. Geomorphoogy 159-160: 116-124. DOI:10.1016/j.geomorph.2012.03.012.

Rennie CD, Church M. 2010. Mapping spatial distributions and uncertainty of water and sediment flux in a large gravel bed river reach using an acoustic Doppler current profiler. Journal of Geophysical Research - Earth Surface 115(F3): 2003-2012. DOl:10.1029/ 2009JF001556.

Rickenmann D, McArdell BW. 2007. Continuous measurement of sediment transport in the Erlenbach stream using piezoelectric bedload impact sensors. Earth Surface Processes and Landforms 32: 1362-1378. DOI:10.1002/esp.1478.

Rickenmann D, Turowski JM, Fritschi B, Klaiber A, Ludwig A. 2012. Bedload transport measurements at the Erlenbach stream with geophones and automated basket samplers. Earth Surface Processes and Landforms 37: 1000-1011. DOl:10.1002/esp.3225.

Rickenmann D, Turowski JM, Fritschi B, Wyss C, Laronne JB, Barzilai R, Reid I, Kreisler A, Aigner J, Seitz H, Habersack H. 2014. Bedload transport measurements with impact plate geophones: comparison of sensor calibration in different gravel-bed streams. Earth Surface Processes and Landforms 39: 928-942. DOl:10.1002/esp.3499.

Schälchli U. 1992. The clogging of coarse gravel river beds by fine sediment. Hydrobiologia 235-236: 189-197. DOI:10.1007/BF00026211.

Schmelter ML, Erwin SO, Wilcock PR. 2012. Accounting for uncertainty in cumulative sediment transport using Bayesian statistics. Geomorphology 175-176: 1-13. DOI:10.1016/j. geomorph.2012.06.012.

Schmelter ML, Hooten MB, Stevens DK. 2011. Bayesian sediment transport for unisize bed load. Water Resources Research 47: W11514.

Shields A. 1936. Anwendung der Aehnlichkeitsmechanik und der Turbulenzforschung auf die Geschiebebewegung. Mitt. Preuss. Versuchsanst. WasserbauSchiffbau, 26. (English translation by Ott WP, van Uchelen JC, US Department of Agriculture, Soil Conservation Service Cooperative Laboratory, California Institute of Technology: Pasadena, CA, 1936; 36 pp.)

Snyder NP, Castele MR, Wright JR. 2008. Bedload entrainment in lowgradient paraglacial coastal rivers of Maine, U.S.A.: implications for habitat restoration. Geomorphology 103: 430-446. DOI:10.1016/j. geomorph.2008.07.013.

Surian N, Barban M, Ziliani L, Monegato G, Bertoldi W, Comiti F. 2015. Vegetation turnover in a braided river: frequency and effectiveness of floods of different magnitude. Earth Surface Processes and Landforms 40: 542-558. DOI:10.1002/esp.3660.

Surian N, Cisotto A. 2007. Channel adjustments, bedload transport and sediment sources in a gravel-bed river, Brenta River, Italy. Earth Surface Processes and Landforms 32(11): 1641-1656. DOl:10.1002/esp.1591.

Surian N, Ziliani L, Comiti F, Lenzi MA, Mao L. 2009. Channel ad- Q17 justments and alteration of sediment fluxes in gravel-bed rivers of northeastern Italy: potentials and limitations for channel recovery. River Research and Applications 25(5): 551-567. DOI:10.1002/ rra.1231.

Thorne PD, Hanes DM. 2002. A review of acoustic measurements of small-scale sediment processes. Continental Shelf Research 22: 603-632. DOI:10.1016/S0278-4343(01)00101-7.

Tockner K, Ward JV, Arscott DB, Edwards PJ, Kollmann J, Gurnell AM, Petts GE, Maiolini B. 2003. The Tagliamento River: a model ecosystem of European importance. Aquatic Sciences 65: 239-253. DOI:10.1007/s00027-003-0699-9.

Vericat D, Church M, Batalla RJ. 2006a. Bed load bias: comparison of measurements obtained using two $(76$ and $152 \mathrm{~mm}$ ) Helley-Smith samplers in a gravel bed river. Water Resources Research 42: W01402. DOI:10.1029/2005WR004025.

Vericat D, Batalla RJ, Garcia C. 2006b. Breakup and reestablishment of the armour layer in a large gravel-bed river below dams: the lower Ebro. Geomorphology 76: 122-136. DOI:10.1016/j. geomorph.2005.10.005.

Wathen SJ, Hoey TB, Werritty A. 1997. Quantitative determination of Q19 the activity of within-reach sediment storage in a small gravel-bed river using transit time and response time. Geomorphology 20: 113-134. DOI:10.1016/S0169-555X(97)00009-3.

Welber M, Bertoldi W, Tubino M. 2012. . The response of braided plan- Q21 form configuration to flow variations, bed reworking and vegetation: the case of the Tagliamento River, Italy. Earth Surface Processes and Landforms 37(5): 572-582. DOI:10.1002/esp.3196.

Wilcock PR. 1993. Critical shear stress of natural sediments. Journal of Hydraulic Engineering 119(4): 491-505. DOI:10.1061/(ASCE)07339429(1993)119:4(491).

Wilcock PR. 1997. Entrainment, displacement, and transport of tracer gravels. Earth Surface Processes and Landforms 22: 1125-1138.

Wilcock PR, Barta AF, Shea CG, Kondolf GM, Matthews WVG, Pitlick J. Q23 1996. Observations of flow and sediment entrainment on a large gravel-bed river. Water Resources Research 32: 2897-2909. DOI:10.1029/96WR01628.

Wilcock PR, Crowe JC. 2003. Surface-based transport model for mixedsize sediment. Journal of Hydraulic Engineering 129: 120-128. DOI:10.1061//(ASCE)0733-9429(2003)129:2(120). 
Wilcock PR, McArdell BW. 1997. Partial transport of a sand/gravel sediment. Water Resources Research 33(1): 235-245. DOI:10.1029/ 96WR02672.

Wittenberg L, Newson MD. 2005. Particle clusters in gravel-bed rivers: an experimental morphological approach to bed material transport and stability concepts. Earth Surface Processes and Landforms 30: 1351-1368. DOI:10.1002/esp.1184.

Wong M, Parker G. 2006. Reanalysis and correction of bed-load relation of Meyer-Peter and Müller using their own database. Journal of Hydraulic Engineering 132: 1159. DOI:10.1061/(ASCE)0733-9429 (2006)132:11(1159).
Zanoni L, Gurnell AM, Drake N, Surian N. 2008. Island dynamics in a braided river from analysis of historical maps and air photographs. River Research and Applications 24: 1141-1159. DOI:10.1002/ rra.1086.

Ziliani L, Surian N. 2012. Evolutionary trajectory of channel morphol- Q27 ogy and controlling factors in a large gravel-bed river. Geomorphology 173-174: 104-117. DOI:10.1016/j.geomorph.2012.06.001.

Ziliani L, Surian N, Coulthard TJ, Tarantola S. 2013. Reduced-complexity modeling of braided rivers: Assessing model performance by sensitivity analysis, calibration, and validation. Journal of Geophysical Research - Earth Surface 118: 2243-2262. DOI:10.1002/jgrf.20154. 


\section{Author Query Form}

\section{Journal: Earth Surface Processes and Landforms}

\section{Article: esp_4000}

Dear Author,

During the copyediting of your paper, the following queries arose. Please respond to these by annotating your proofs with the necessary changes/additions.

- If you intend to annotate your proof electronically, please refer to the E-annotation guidelines.

- If you intend to annotate your proof by means of hard-copy mark-up, please use the standard proofing marks. If manually writing corrections on your proof and returning it by fax, do not write too close to the edge of the paper. Please remember that illegible mark-ups may delay publication.

Whether you opt for hard-copy or electronic annotation of your proofs, we recommend that you provide additional clarification of answers to queries by entering your answers on the query sheet, in addition to the text mark-up.

\begin{tabular}{|c|c|c|}
\hline Query No. & Query & Remark \\
\hline Q1 & $\begin{array}{l}\text { AUTHOR: Please confirm that given names (red) and surnames/family names (green) } \\
\text { have been identified correctly. }\end{array}$ & \\
\hline Q2 & $\begin{array}{l}\text { AUTHOR: There are two references Vericat et al., } 2006 \text { in the reference list, please } \\
\text { confirm Vericat et al., 2006a is the reference being referred to here, or correct. }\end{array}$ & \\
\hline Q3 & $\begin{array}{l}\text { AUTHOR: The reference Hilldale et al., } 2014 \text { has been changed to Hilldale et al., } 2015 \\
\text { to match the entry in the reference list, please confirm or correct. }\end{array}$ & \\
\hline Q4 & AUTHOR: Please confirm or correct. & \\
\hline Q5 & $\begin{array}{l}\text { AUTHOR: There are two references Vericat et al., } 2006 \text { in the reference list, please } \\
\text { confirm Vericat et al., 2006b is the reference being referred to here, or correct. }\end{array}$ & \\
\hline Q6 & AUTHOR: Please provide full reference details for Chinello, 2006. & \\
\hline Q7 & AUTHOR: Please provide full reference details for Carson and Griffiths (1989). & \\
\hline Q8 & AUTHOR: Please provide full reference details for Nicholas (1999). & \\
\hline Q9 & AUTHOR: Please provide full reference details for Barry et al., 2004. & \\
\hline Q10 & AUTHOR: PLease provide full reference details for Grams and Wilcock, 2014. & \\
\hline Q11 & $\begin{array}{l}\text { AUTHOR: References "Haschenburger, 1999, Kaless et al., 2014, Surian et al., 2009, } \\
\text { Vericat et al., 2006a, Vericat et al., 2006b, Wathen et al., 1997, Welber et al., 2012, } \\
\text { Wilcock et al., 1996, Zanoni et al., 2008, Ziliani \& Surian, 2012" were not cited } \\
\text { anywhere in the text. Please provide a citation. Alternatively, delete the items from } \\
\text { the list. }\end{array}$ & \\
\hline Q12 & $\begin{array}{l}\text { AUTHOR: Reference "Haschenburger, 1999" is not cited in the text. Please indicate } \\
\text { where it should be cited; or delete from the reference list and renumber the } \\
\text { references in the text and reference list. }\end{array}$ & \\
\hline Q13 & $\begin{array}{l}\text { AUTHOR: Please cite Haschenburger, } 1999 \text { in the text, or remove from the reference } \\
\text { list. }\end{array}$ & \\
\hline Q14 & $\begin{array}{l}\text { AUTHOR: Reference "Kaless et al, 2014" is not cited in the text. Please indicate where } \\
\text { it should be cited; or delete from the reference list and renumber the references in the } \\
\text { text and reference list. }\end{array}$ & \\
\hline Q15 & AUTHOR: Please cite Kaless et al., 2014 in the text, or remove from the reference list. & \\
\hline Q16 & AUTHOR: Please cite Surian et al., 2015 in the text, or remove from the reference list. & \\
\hline Q17 & $\begin{array}{l}\text { AUTHOR: Reference "Surian et al, 2009" is not cited in the text. Please indicate where } \\
\text { it should be cited; or delete from the reference list and renumber the references in the } \\
\text { text and reference list. }\end{array}$ & \\
\hline
\end{tabular}




\begin{tabular}{|c|c|c|}
\hline Query No. & Query & Remark \\
\hline Q18 & AUTHOR: Please cite Surian et al., 2009 in the text, or remove from the reference list. & \\
\hline Q19 & $\begin{array}{l}\text { AUTHOR: Reference "Wathen et al, 1997" is not cited in the text. Please indicate } \\
\text { where it should be cited; or delete from the reference list and renumber the } \\
\text { references in the text and reference list. }\end{array}$ & \\
\hline Q20 & AUTHOR: Please cite Wathen et al., 1997 in the text, or remove from the reference list. & \\
\hline Q21 & $\begin{array}{l}\text { AUTHOR: Reference "Welber et al, 2012" is not cited in the text. Please indicate } \\
\text { where it should be cited; or delete from the reference list and renumber the } \\
\text { references in the text and reference list. }\end{array}$ & \\
\hline Q22 & AUTHOR: Please cite Welber et al., 2012 in the text, or remove from the reference list. & \\
\hline Q23 & $\begin{array}{l}\text { AUTHOR: Reference "Wilcock et al, } 1996 " \text { is not cited in the text. Please indicate } \\
\text { where it should be cited; or delete from the reference list and renumber the } \\
\text { references in the text and reference list. }\end{array}$ & \\
\hline Q24 & $\begin{array}{l}\text { AUTHOR: Please cite Wilcock et al., } 1996 \text { in the text, or remove from the reference } \\
\text { list. }\end{array}$ & \\
\hline Q25 & $\begin{array}{l}\text { AUTHOR: Reference "Zanoni et al, } 2008 \text { " is not cited in the text. Please indicate } \\
\text { where it should be cited; or delete from the reference list and renumber the } \\
\text { references in the text and reference list. }\end{array}$ & \\
\hline Q26 & AUTHOR: Please cite Zanoni et al., 2008 in the text, or remove from the reference list. & \\
\hline Q27 & $\begin{array}{l}\text { AUTHOR: Reference "Ziliani \& Surian, 2012" is not cited in the text. Please indicate } \\
\text { where it should be cited; or delete from the reference list and renumber the references in } \\
\text { the text and reference list. }\end{array}$ & \\
\hline Q28 & $\begin{array}{l}\text { AUTHOR: Please cite Ziliani and Surian, } 2012 \text { in the text, or remove from the } \\
\text { reference list. }\end{array}$ & \\
\hline
\end{tabular}


Required software to e-Annotate PDFs: Adobe Acrobat Professional or Adobe Reader (version 7.0 or above). (Note that this document uses screenshots from Adobe Reader $\mathrm{X}$ )

The latest version of Acrobat Reader can be downloaded for free at: http://get.adobe.com/uk/reader/

Once you have Acrobat Reader open on your computer, click on the Comment tab at the right of the toolbar:

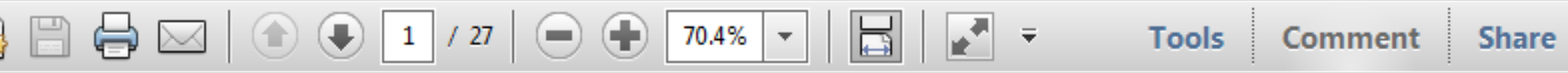

This will open up a panel down the right side of the document. The majority of tools you will use for annotating your proof will be in the Annotations section, pictured opposite. We've picked out some of these tools below:

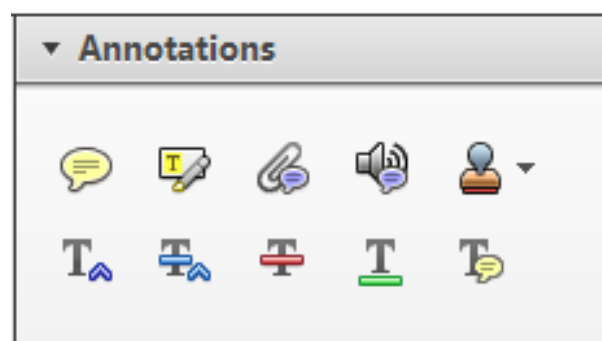

1. Replace (Ins) Tool - for replacing text.

Strikes a line through text and opens up a text box where replacement text can be entered.

How to use it

- Highlight a word or sentence.

- Click on the Replace (Ins) icon in the Annotations section.

- Type the replacement text into the blue box that appears.

Idard tramework for the analysis of $\mathrm{m}$ icy-Nevertheless, it also led to exog،

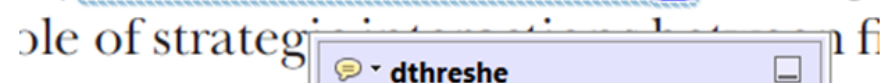
aber of comp 08/06/2011 15:58:17 is that the s1 nain compo: be level, are exc nc

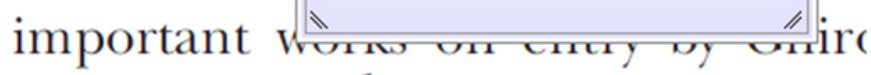
M heneferth) ${ }^{1}$ we anen the "hlarl $\mathrm{l}$

3. Add note to text Tool - for highlighting a section to be changed to bold or italic.

T Highlights text in yellow and opens up a text box where comments can be entered.

\section{How to use it}

- Highlight the relevant section of text.

- Click on the Add note to text icon in the Annotations section.

- Type instruction on what should be changed regarding the text into the yellow box that appears.

namic responses of mark ups ent with the VAR evidence

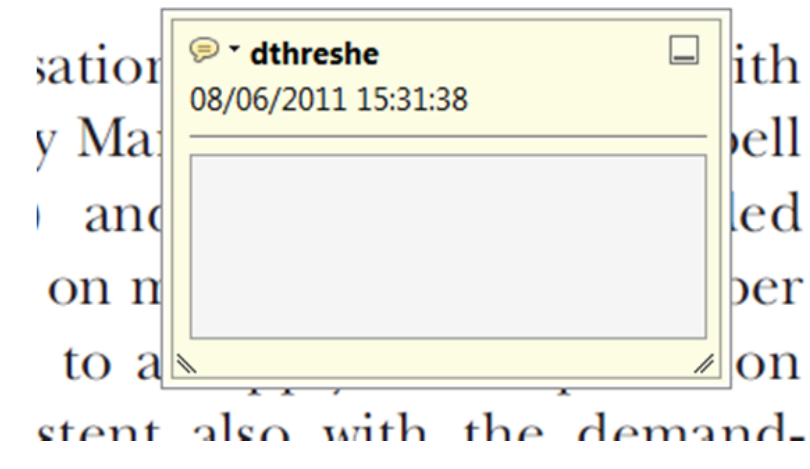

2. Strikethrough (Del) Tool - for deleting text.

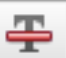

Strikes a red line through text that is to be deleted.

How to use it

- Highlight a word or sentence.

- Click on the Strikethrough (Del) icon in the Annotations section.

there is no room tor extra prohts al c ups are zero and the number of ret) values are not determined by Blanchard and Kiyotaki (1987), sfect competition in general equilil ts of aggregate demand and supply lassical framework assuming monol eph on evorenous number of firme

4. Add sticky note Tool - for making notes at specific points in the text.

Marks a point in the proof where a comment needs to be highlighted.

How to use it

- Click on the Add sticky note icon in the Annotations section.

- Click at the point in the proof where the comment should be inserted.

- Type the comment into the yellow box that appears.

iaisu airu suppiy sirucks. hivsl ui

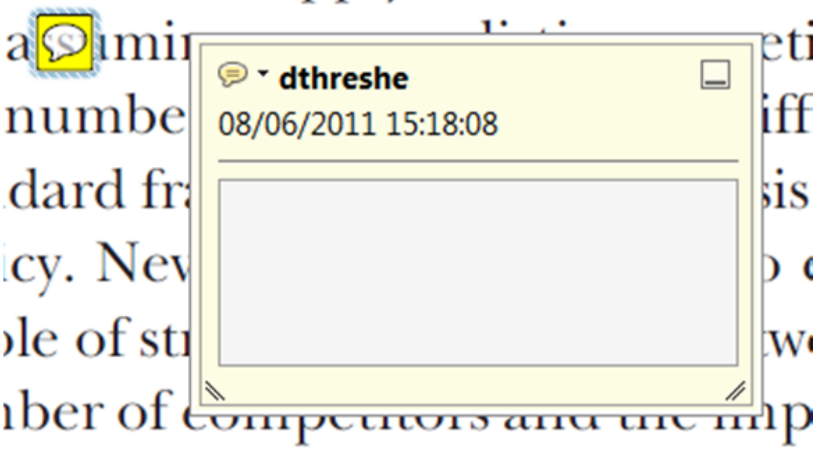

is that the structure of the secto. 
5. Attach File Tool - for inserting large amounts of text or replacement figures.

Inserts an icon linking to the attached file in the appropriate pace in the text.

How to use it

- Click on the Attach File icon in the Annotations section.

- Click on the proof to where you'd like the attached file to be linked.

- Select the file to be attached from your computer or network.

- Select the colour and type of icon that will appear in the proof. Click OK.

E N D

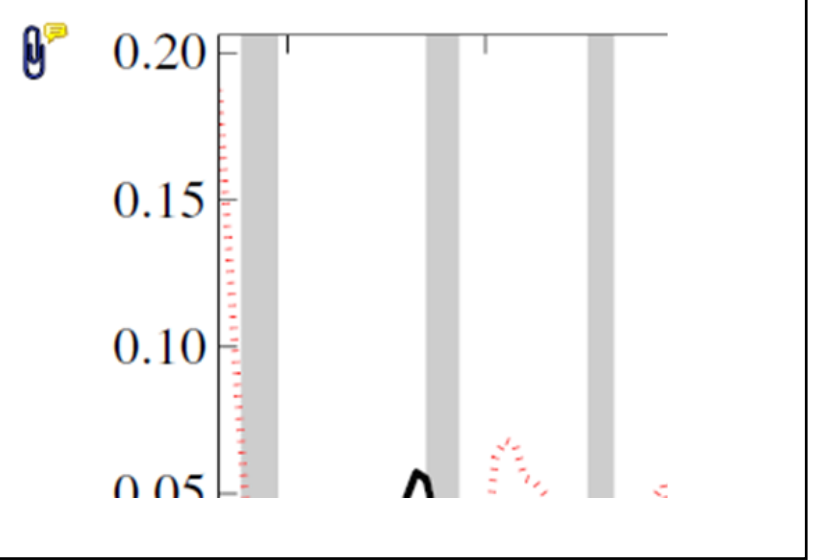

6. Add stamp Tool - for approving a proof if no corrections are required.

- Inserts a selected stamp onto an appropriate place in the proof.

\section{How to use it}

- Click on the Add stamp icon in the Annotations section.

- $\quad$ Select the stamp you want to use. (The Approved stamp is usually available directly in the menu that appears).

- Click on the proof where you'd like the stamp to appear. (Where a proof is to be approved as it is, this would normally be on the first page).

or the business cycie, starting with the on perfect competition, constant ret

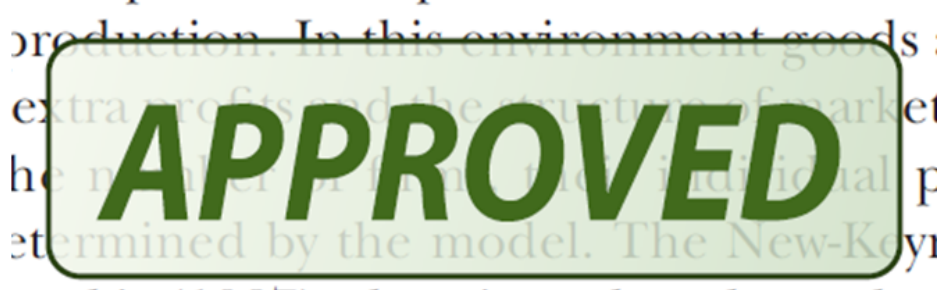
otaki (1987), has introduced produc general equilibrium models with nomin:

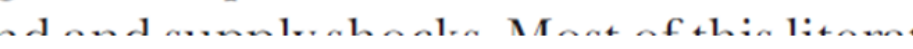

- Drawing Markups

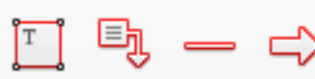

$0 \bigcirc \sqrt{6} \otimes$

\section{How to use it}

- Click on one of the shapes in the Drawing Markups section.

- Click on the proof at the relevant point and draw the selected shape with the cursor.

- To add a comment to the drawn shape, move the cursor over the shape until an arrowhead appears.

- Double click on the shape and type any text in the red box that appears.
7. Drawing Markups Tools - for drawing shapes, lines and freeform annotations on proofs and commenting on these marks.

Allows shapes, lines and freeform annotations to be drawn on proofs and for comment to be made on these marks.

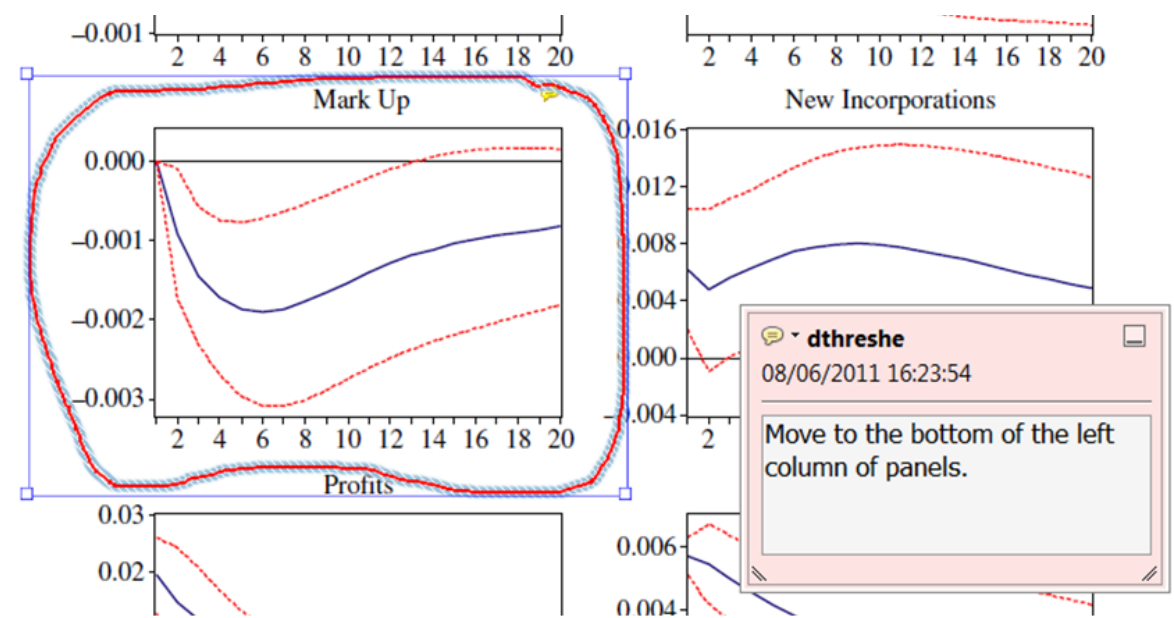

For further information on how to annotate proofs, click on the Help menu to reveal a list of further options:

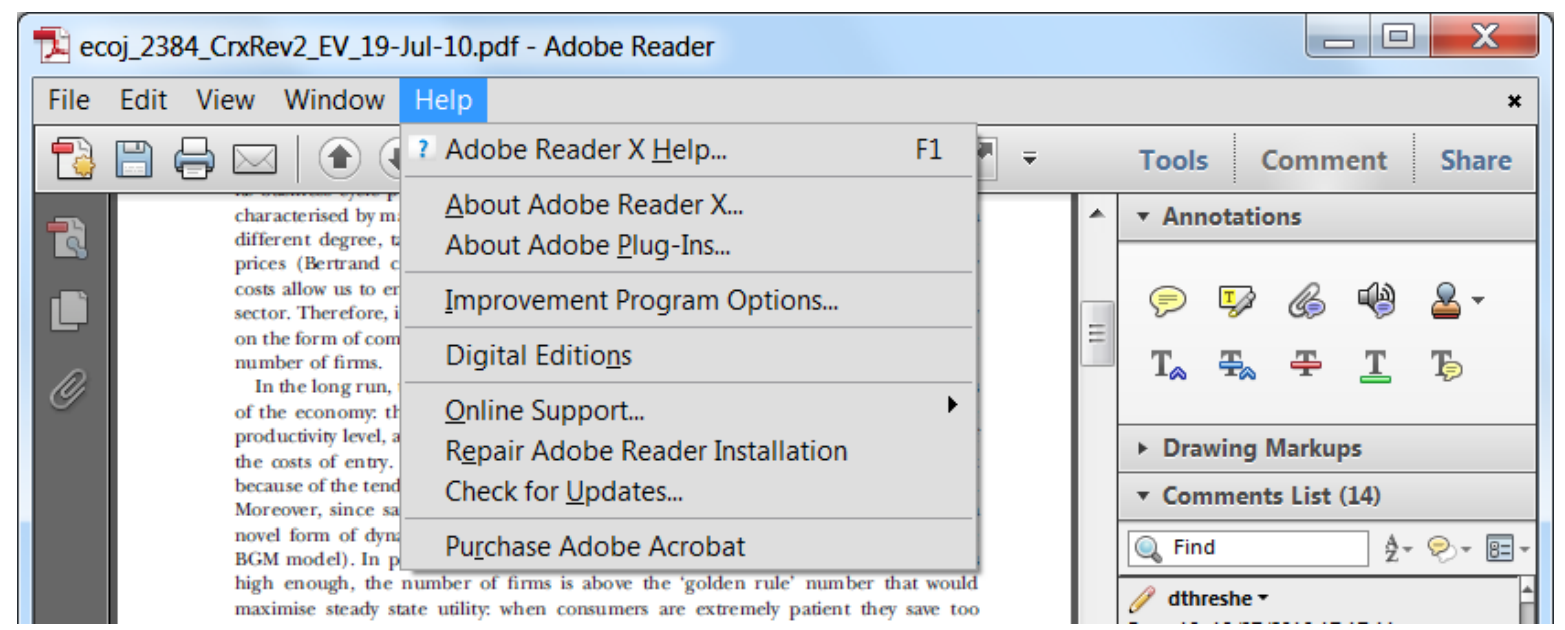

